NBER WORKING PAPER SERIES

\title{
CALIFORNIA ENERGY EFFICIENCY: LESSONS FOR THE REST OF THE WORLD, OR NOT?
}

\author{
Arik Levinson \\ Working Paper 19123 \\ http://www.nber.org/papers/w19123 \\ NATIONAL BUREAU OF ECONOMIC RESEARCH \\ 1050 Massachusetts Avenue \\ Cambridge, MA 02138 \\ June 2013
}

Thanks to Jason Bordoff for asking the question that led to this project, Joe Aldy, Matt Harding, and James O'Brien, and Rob Stavins for helpful feedback, Jenna Kirschner for exceptionally thorough and resourceful research assistance, and Randy Becker at the Census Bureau for help with the crosswalk between SIC and NAICS industry codes. The views expressed herein are those of the author and do not necessarily reflect the views of the National Bureau of Economic Research.

NBER working papers are circulated for discussion and comment purposes. They have not been peerreviewed or been subject to the review by the NBER Board of Directors that accompanies official NBER publications.

(C) 2013 by Arik Levinson. All rights reserved. Short sections of text, not to exceed two paragraphs, may be quoted without explicit permission provided that full credit, including $\odot$ notice, is given to the source. 
California Energy Efficiency: Lessons for the Rest of the World, or Not?

Arik Levinson

NBER Working Paper No. 19123

June 2013

JEL No. Q4

\begin{abstract}
$\underline{\text { ABSTRACT }}$
Starting in the 1970s California's residential electricity consumption per capita stopped increasing, while other states' electricity use continued to grow steadily. Similar patterns can be seen in non-electric energy, industry, and transportation. What accounts for California's apparent energy savings? Some credit the strict energy efficiency standards for buildings and appliances enacted by California in the mid-1970s. They argue that other states and countries could replicate California's gains, and that California should build on its own success by tightening those standards further. Skeptics might point to three long-run trends that differentiate California's electricity demand from other states: (1) shifting of the U.S. population towards warmer climates of the South and West; (2) relatively small income elasticity of energy demand in California's temperate climate; and (3) evolving differences between the demographics of households in California and other states. Together, these trends account for around 90 percent of California's apparent residential electricity savings, thus providing no lessons for other states or countries considering adopting or tightening their energy efficiency standards.
\end{abstract}

Arik Levinson

Department of Economics ICC 571

Georgetown University

3700 O St., NW

Washington, DC 20057

and NBER

aml6@georgetown.edu 


\section{California's Energy Efficiency: Lessons for the Rest of the World, or Not?}

For the past 40 years, residential electricity consumption per capita has remained nearly constant in California while growing by 75 percent in the rest of the United States. These starkly different trends, plotted in Figure 1, serve as a key piece of evidence supporting the types of government-mandated energy-efficiency policies California implemented in the 1970s. Yet the figure by itself does not reveal the reason for California's slower electricity consumption growth or whether those savings could be replicated by other states or countries.

Proponents of regulations give credit for California's apparent savings to the California Energy Commission (CEC), which set the nation's first energy efficiency standards for appliances and buildings, and to the California Public Utility Commission (CPUC), which led the country in decoupling utility profits from sales of electricity and natural gas (Rosenfeld and Poskanzer, 2009). California regulators claim that "because of its energy efficiency standards and program investments, electricity use per person in California has remained relatively stable over the past 30 years, while nationwide electricity use has increased." ${ }^{1}$ U.S. Energy Secretary Steven Chu attributes California's savings to its "progressive energy policies." ${ }^{2}$ The Natural Resources Defense Council asserts that California's policies "offer lessons to states and utilities outside California" (Ettenson, 2011). And the World Bank devoted an entire page of its 2010 World Development Report to California and a reproduction of Figure 1 as a lesson for the rest of the world. In this view, other states and countries could achieve California-sized energy savings by adopting California-style regulations like those in Table 1.

There are, however, reasons to be skeptical about attributing California's apparent savings in Figure 1 to regulatory changes. First, appliance manufacturers quickly began meeting California's energy efficiency standards nationwide, rather than designing and producing two sets of products. Second, other states and the federal government soon followed California's lead. Third, California's relative energy savings, depicted by the bottom line in Figure 1, appear as a steady trend that begins before 1970, long before the state's regulations took effect. And fourth, the energy savings have occurred in all sectors, even those not targeted by the regulations. That leaves open the question of what does explain the savings.

If regulations do not deserve credit for California's declining relative electricity consumption, what can? This paper investigates three hypotheses: population migration, climate, and demographics. ${ }^{3}$ First: migration. Over the past several decades, the United States population has shifted from the North and East to the South and Southwest. The Southwest has larger homes and higher demand for air conditioning, leading to higher energy consumption. Second: climate.

\footnotetext{
${ }^{1}$ California Public Utilities Commission and California Energy Commission, "Energy Efficiency: California's Highest-Priority Resource" June 2006.

${ }^{2}$ Steven Chu interviewed by Larry Klein and published in NOVA Online January 20, 2009. (www.pbs.org/wgbh/nova/tech/energy-secretary-chu.html)

${ }^{3}$ See, for example, Tanton (2008), Clemente (2011), and Mitchell et al. (2009).
} 
California's mild climate means that five decades of income and home size growth nationwide has translated into less increased heating and cooling in California than in other states. And third: demographics. Household sizes have shrunk less in California than in the rest of the country, so that California households have gained on average 0.6 members relative to households in other states. Since energy use per capita declines with household size, Californians' electricity use has increased less than that in other states. In this skeptical view, California's declining relative energy consumption has been coincidental, has little to do with regulatory decisions the state made in the 1970s, and cannot be replicated by other states or nations.

This paper is not the first to attempt to assess the cause of California's energy efficiency gains, but the approach I take is somewhat new. I do not take the bottom-up engineering approach typical of regulatory impact analyses conducted by government agencies proposing efficiency standards. Engineering analyses typically disregard consumers' reactions to changes in energy efficiency. One potentially important reaction would be to use more energy - the Jevons paradox or "rebound effect." Standards that make appliances and buildings more energy efficient lower the cost of energy services, which may in turn increase energy consumption and offset some of the mandated efficiency gains. If bottom-up analyses assume that a regulation requiring air conditioners to be 30 percent more energy efficient will result in 30 percent less energy consumption, those analyses will overstate the energy-per-capita savings resulting from the regulation.

Nor do I take a completely top-down approach and try to work all of the explanations into one comprehensive model, such as a regression framework where multiple state characteristics explain state energy consumption. Mitchell, et al. (2009), for example, discuss a regression of per capita energy use on energy efficiency standards and other state characteristics, finding that only 20 percent of California's per capita energy savings come from the standards. But that type of approach is sensitive to the choice of functional form and complicated by interaction effects among the various external factors. An increasingly less energy intensive industrial base might drive down the relative price of electricity and increase consumer demand. An increasing share of immigrants in the population has changed California's household size and income distribution, with different effects on energy consumption. Costa and Kahn (2010) regress electricity consumption on house and household characteristics for customers of a California utlity from 2000 to 2009. That approach provides an excellent characterization of California households' current electricity consumption, but less information about how that consumption compares to other states or has changed since the 1960s.

Instead of a bottom-up or top-down model, I take more of a piece-by-piece accounting approach, similar to that taken by Sudarshan (2010). Taking each of the three skeptical hypotheses in turn, I ask how much of the perceived residential electricity savings can be explained by factors unrelated to the regulations. How much less electricity would the rest of the country be using had the population not shifted to states with warmer climates and greater demand for air conditioning? How much of California's apparent savings stem from the fact that 
nationwide income growth leads to more space-heating and cooling in states with less temperate climates? And how much California's savings can be explained by changes in California's demographics - age, household size, income, etc. - relative to other states?

The question posed here, how much of California's energy savings can be explained by coincidental trends rather than the state's regulations, takes on increasing importance as both California and federal regulators propose tightening energy efficiency standards even further. California's Global Warming Solutions Act of 2006 aims to reduce greenhouse gas emissions in the state to 1990 levels by 2020; 18 percent of those reductions are expected to come from new, stricter energy efficiency standards for buildings and utilities, and another 26 percent from stricter standards for vehicles (CARB, 2008, p.17). Massachusetts's Global Warming Solutions Act of 2008 proposes to reduce GHG emissions in that state by 27 percent below its 1990 levels; 36 percent of those gains are projected to come from energy efficiency improvements to buildings and appliances. ${ }^{4}$ And similarly the climate bill that passed the U.S. House of Representatives in 2009 would have required substantially increased energy efficiency from new buildings, appliances, and vehicles.

The results of this exercise suggest that California's regulations have not been the main cause of its electricity savings relative to the rest of the U.S. The trend began before 1973, seems unaffected by regulatory changes, and appears in sectors not targeted by those changes.

Residential electricity shows the most dramatic apparent savings, but those gains appear almost entirely driven by the shifting of the U.S. population to the Southwest, California's relatively mild climate, and other demographic differences between California and other states.

\section{Aside: Energy Savings in Other Sectors}

Although residential electricity has been the focus of claims about the success of regulatory policy, figures similar to Figure 1 drawn for other energy uses show similar patterns. Table 2 makes this point. The top row of Table 2 displays the data for California's total energy consumption, which was 217 Million BTU (MBTU) per capita in 2009. If California energy use had grown at the same rate as other states in percentage terms, it would have been $269 \mathrm{MBTU}$ per capita in 2009; if California energy use had grown at the same rate in absolute terms, it would have been 283 MBTU. ${ }^{5}$ The difference, 52 or $66 \mathrm{MBTU}$ in columns (5) and (6) of Table 2 , means that total energy consumption in California fell 19 or 23 percent relative to those other states. Had the rest of the country mimicked California's trajectory, total national energy consumption by 2009 would have been lower by an amount sufficient to achieve the Obama

\footnotetext{
${ }_{5}^{4}$ Massachusetts Secretary of Energy and Environmental Affairs, 2010, p. ES-6.

${ }^{5}$ Since California had lower per-capita energy consumption than other states in 1963, an equal proportional increase in California's energy use would result in a smaller absolute increase.
} 
Administration's goal of reducing U.S. greenhouse gas emissions to 17 percent below 2005 levels by $2020 .^{6}$

Figure 2 graphs these calculations, using the data from columns (1) and (5) of Table 2. The height of each column represents what each sector's per capita energy consumption would have been in 2009 in California had it changed by the same percentage as in other states since 1963. The height of the solid portion of each column represents California's actual consumption in 2009. The difference, cross-hatched in the figure, represents California's per capita savings from each sector relative to national energy use.

Table 2 and Figure 2 make two important points. First, all sectors contributed to the relative decline in California's energy consumption per capita. Even sectors where per capita consumption grew substantially in California, such as transportation and commercial energy, consumption grew faster in other states. Second, sectors with the most dramatic apparent savings - residential and commercial electricity - account for a relatively small fraction of overall savings because they represent a small part of states' energy budgets. In the end, how much each sector really contributes to energy efficiency savings depends on how much of those savings comes from energy efficiency and how much comes from other factors driving energy consumption, including geography and climate, household demographics, industrial composition, and transportation patterns.

In what follows I briefly discuss manufacturing and transportation, sectors with smaller percentage savings but larger shares of states' overall energy budgets. But first I focus on the sector featured in Figure 1 and numerous campaigns to promote mandated efficiency standards: residential electricity.

\section{Residential Electricity: Population Shifts, Climate, and the Income Elasticity of Heating and Cooling}

Figure 1 shows that from 1963 to 2009 , residential electricity consumption per capita grew by 120 percent in California and 245 percent in other states. Skeptics of regulations as an explanation for the difference offer three main alternatives. First, the U.S. population shifted from the North and East to the South and West, driving up demand for air conditioning and electricity in states other than California. Second, even if the population hadn't moved, household incomes grew. Because California has a mild climate, the income elasticity of demand for space heating and cooling is lower there and energy consumption grew less. In this section, I discuss each explanation in turn. In the next section I discuss a third explanation; California

\footnotetext{
${ }^{6}$ Energy use accounted for 87 percent of U.S. greenhouse gas emissions in 2009 (EPA, 2011, p.3-1), and 20 percent reduction of 87 is just over 17 percent.
} 
incomes shrank and household sizes grew relative to other states, and with those changes came declines in energy consumption per capita.

\section{Population Shifts}

Since 1963 the population of the Northeast and Midwest grew by 23 percent, while the South grew 96 percent, the West 130 percent, and the Mountain West 190 percent. This disproportionate growth in regions with different patterns of energy use could be one reason why California's energy consumption per capita fell behind that of other states.

The simplest way of assessing how population shifts contributed to California's apparent energy savings is to create a version of Figure 1 that holds the populations of the other states fixed. Figure 1 compares California's energy consumption per capita to energy consumption per capita in all other states combined:

$$
\theta_{t}=\frac{1}{P_{t}^{\prime}} \sum_{s \neq C A} \theta_{s t} P_{s t}
$$

where $\theta_{t}$ is the energy use per capita in year $t$ in states other than California, $P_{t}^{\prime}$ is the total population of the other, non-California, states, and $\theta_{s t}$ represents the energy consumption per capita of state $s$ in year $t$, or $\theta_{s t}=E_{s t} / P_{s t}$. This measure, $\theta_{t}$, is simply the weighted average of other states' energy use per capita, where the weights are the other states' populations. It is plotted as the top line in Figure 1, and changes over time because of changes in various states' energy intensities $\left(\theta_{s t}\right)$ and state populations $\left(P_{s t}\right)$.

Instead consider holding population fixed. Compare California's energy intensity to a weighted average of other states' individual energy consumption per capita each year, where the weights are each state's population in 1963:

$$
\hat{\theta}_{t}=\frac{1}{P^{\prime}{ }_{63}} \sum_{s \neq C A} \theta_{s t} P_{s, 63}
$$

This measure changes over time only because energy consumption per capita changes. It describes what would have happened had the population of the U.S. not shifted toward the Southwest, but other states' energy consumption changed. Figure 3 plots this line for residential electricity. By 2009 the line $\hat{\theta}$ had grown by 234 percent, a bit less than the line plotting other states' actual consumption, and this adjustment accounts for 15 percent of the gap between other states' and California's consumption.

Table 3 summarizes this calculation for residential electricity and several other relevant categories of energy use. From 1963 to 2009 other states' residential electricity consumption grew 11.5 MBTU per capita, or 249 percent. Without migration, other states' consumption $(\hat{\theta})$ would have grown $0.7 \mathrm{MBTU}$ less. That difference accounts for 15 percent of California's 
apparent 4.7 MBTU of savings as calculated from other states percentage growth over the period, or 9 percent of California's apparent 7.7 MBTU of savings calculated from other states' absolute growth.

For residential non-electric energy use, however, in the second row of Table 3, the pattern is reversed. Without migration, other states' consumption per capita would have grown 7.7 MBTU per capita rather than the actual 6.4 MBTU, or 1.28 MBTU more. The U.S. population shifted to states that use less non-electric residential energy. Rather than explaining California's apparent non-electric energy savings documented in Table 2 and Figure 2, migration and geography mask some of those savings.

The final column of Table 3 helps explain this difference. It reports the correlation across all 50 states plus the District of Columbia between each jurisdiction's population growth and the various measures of energy intensity, averaged across the time period. That correlation is 0.093 for residential electricity because population grew more in states with higher average residential electricity consumption per capita. Hence migration helps explain 9 to 15 percent of California's apparent savings relative to the rest of the United States. The correlation is -0.42 for residential non-electric energy because the population grew more in states with lower average non-electric energy consumption per capita. So migration masks 12 to 15 percent of California's savings in this category.

The bottom panel of Table 3 presents the same calculation for commercial buildings such as offices, hospitals, hotels, and universities. Most of this sector's energy use comes from space heating, cooling, and lighting, and so it follows the same geographic pattern as residential energy. Two or three percent of California's commercial buildings' electricity savings are explained by population shifts in other states, and that is offset by a 6 or 7 percent swing in the other direction for non-electric energy. The reason the commercial sector's population-related swings are smaller than the residential sector's is also apparent from column (6). State commercial energy use per capita is less strongly correlated with state population growth.

A likely explanation for these patterns is climate. Residences and commercial buildings use electric energy for air conditioning in the Southwest and non-electric energy for space heating in the Northeast. The population shift from Northeast to Southwest has increased demand for residential and commercial electricity nationwide, and decreased demand for other categories of residential and commercial energy. As a result, California's residential and commercial electricity consumption per capita has grown more slowly than in the rest of the United States, and other energy consumption has grown more quickly.

\section{Population Shifts and Climate}

This climate-related explanation for California's efficiency gains can be examined separately. Line (1) of Figure 4 plots the weighted average number of heating degree days in the 
48 contiguous U.S. states other than California, where the weights are the states' populations in each year:

$$
H D D(1)_{t}=\frac{1}{P_{t}^{\prime}} \sum_{s \neq C A} H D D_{s, t} \times P_{s, t}
$$

where $\mathrm{HDD}_{\mathrm{s}, \mathrm{t}}$ is the heating degree days in state $s$ in year $t^{7}$ This calculation changes year-toyear because of both temperature changes and population changes. Line (2) uses the average number of heating degree days for the entire period for each state:

$$
H D D(2)_{t}=\frac{1}{P_{t}^{\prime}} \sum_{s \neq C A} \overline{H D D}_{s} \times P_{s, t}
$$

where $\overline{H D D}_{s}$ is the average number of heating degree days for state $s$ from 1960 to 2010. Its smooth decline results from population changes alone. The average number of heating degree days experienced by a typical non-California American has declined 10 percent, simply because the population has shifted out of the colder Northeast and Midwest.

The bottom two lines in Figure 4 plot cooling degree days in an analogous way. The average number of cooling degree days experienced by a typical non-California American has increased by 19 percent, again simply because the population has shifted to warmer regions. A similar graph for California would show heating degree days flat at 2600 per year, and cooling degree days flat at 900 per year. $^{8}$

To sum up the analysis at this point, geographic shifts in the U.S. population have increased residential and commercial electricity demand, largely due to the increased cooling degree days experienced by the average American outside of California. And the shifts have decreased residential and commercial demand for non-electric energy, largely due to the decreased number of heating degree days.

There may be, however, a second climate-related explanation for California's residential energy savings. Even if the population had not moved disproportionately to states with different patterns of energy use, residential energy consumption might have increased nationwide simply because space heating and cooling are normal goods and household incomes have risen. That trend would matter less in California, where the relatively mild climate means that income

\footnotetext{
${ }^{7}$ A degree day is the difference between the average of the daily maximum and minimum temperatures and $65^{\circ} \mathrm{F}$. A heating degree day occurs when that average temperature is less than $65^{\circ}$, and a cooling degree when it is greater than $65^{\circ}$.

${ }^{8}$ California is large and has had its own share of internal population shifts. Since 1960 California's population has migrated to less temperate but also less wealthy regions, with more heating and cooling degree days but less electricity use per capita. If California's internal migration were added to Figure 3 and Table 3, population shifts would explain even more of the state's apparent energy savings relative to the rest of the country.
} 
elasticities of heating and cooling are smaller. California may have thus avoided some of the increased energy consumption associated with income growth in less temperate states.

\section{Climate and Income}

To test whether California energy demand is less income elastic than other states, and whether this is due to California's mild climate, I regress energy use on regional climate as measured by average heating and cooling degree days, household income, and the interaction between the two.

$$
\begin{aligned}
& B T U_{i}=\alpha+\beta_{1} \overline{H D D}_{i}+\beta_{2} \overline{C D D}_{i}+\beta_{3}\left(\text { income }_{i}\right)+\beta_{4} \overline{H D D}_{i} \times\left(\text { income }_{i}\right)+ \\
& \beta_{5} \overline{C D D}_{i} \times\left(\text { income }_{i}\right)+\beta_{6} h^{\prime} \text { holdsize }_{i}+\beta_{7} \text { trend }_{i}+\sum_{d} \delta_{d} D_{i}+\epsilon_{i}
\end{aligned}
$$

Equation (1) cannot be estimated with the aggregate state data used in the previous sections, because aggregate state incomes only differ across years and it is not possible to separately identify income growth from the other trends that influence residential energy use. Instead, I need to use household data, so that I can compare energy use by households with different incomes, in the same year and place, and then to forecast how much energy use increases with income, and how that increase might differ for California's mild climate. For that I turn to the Residential Energy Consumption Survey (RECS). The RECS does not identify individual states, except a few large ones including California, but does identify nine census divisions, so in equation (1) $\overline{H D D}$ and $\overline{C D D}$ refer to the average annual HDD and CDD in household $i$ 's census division, and $\delta_{d}$ refers to fixed effects by census division. I include household size as the one extra demographic covariate.

Table 4 contains an estimate of equation (1). Marginal effects calculated from interaction coefficients at the means of right-hand-side variables are at the bottom of the table. Electricity use increases with household income at the mean levels of HDD and CDD, and electricity use increases faster with income in hotter areas (higher CDD). The coefficient on cooling days and its interaction with income, for example, suggests that an extra 100 cooling degree days (or 10 days of 10-degree hotter weather) is associated with an extra 680 BTUs of electricity use for a household with the mean income, or about 4 percent. $^{9}$

Table 5 reports the magnitude of these effects. Using the point estimates in Table 4, an extra $\$ 1000$ of income increases per capita electricity consumption for the average household by 11,900 BTUs in California and 50,200 BTUs in other states. ${ }^{10}$ Income growth adds less to California's residential electricity demand than to other states because of California's mild climate. How large is this effect? From 1963 to 2009, real mean household income in the United States grew by more than 50 percent, from $\$ 44$ thousand to $\$ 69$ thousand. Applying the predictions from Table 4 and Table 5, this would increase electricity use per capita by 959,000

\footnotetext{
${ }^{9} 680=100 \times(4.73+0.0386 \times 53.1)$.

${ }^{10}$ For California: $11.9=1 \times(-52.02+0.0112 \times(2601$ HDDs $)+0.0386 \times(901$ CDDs $))$.
} 
BTUs in California relative to other states. Recall from Table 2 that California appears to have saved 4.7 MBTU per capita of residential electricity relative to other states. It seems that a significant fraction - around 20 percent - of those savings come from California's mild climate and low income elasticity of energy consumption. This calculation is reported in the bottom row of Table 5 .

The first of the skeptical explanations is that California's apparent electricity savings come from the particular geography of the United States combined with regional patterns of population shifts and California's mild climate. Figure 1 suggests that since 1963 California has saved 4.7 MBTU of residential electricity per capita relative to other states, or 36 percent. The calculations in this section indicate that part of those savings is illusory: 15 percent of the savings can be explained by the U.S. population shift to warmer climates that use more air conditioning and 20 percent by the fact that income growth in California's mild climate has not led to more air conditioning. But that leaves another 65 percent of the residential electricity savings in Figure 1 unexplained, and it does not account for the apparent savings in non-electric energy use, where migration patterns work in the opposite direction and mask some potential energy efficiency gains in California. For those reasons, in the next section I explore the other proffered explanation for Figure 1: differences between the demographic changes in California and in other U.S. states.

\section{Residential Electricity: Population and Housing Characteristics}

A second hypothesis for California's apparent energy savings involves the changing composition of California's demographics relative to other U.S. states. Table 6 documents a set of simple descriptive statistics and their changes. ${ }^{11}$ Some of the differences between California and other states are stark. Household incomes grew nationwide, but by 26 percent less in California relative to other states. The number of occupants per home fell nationwide, but fell by 0.6 fewer in California.

In considering how these demographic changes might affect energy consumption and explain California's apparent savings, we need to be careful as to which characteristics are exogenous and not replicable elsewhere, compared with those that may be driven by policy, either intentionally or not. For example, the number of children living in the average household fell throughout the U.S., but fell less quickly in California. Over the past 50 years, the average California household gained 0.23 children relative to other states' households. This change in household size could have implications for energy consumption, but it seems unlikely that energy regulations caused those fertility changes and implausible that states would use fertility policies as a mechanism for energy savings. On the other hand, while house sizes have been growing throughout the U.S., the number of rooms in the typical California home fell over the

\footnotetext{
${ }^{11}$ Some statistics come from the decennial U.S. Census and are only available for 1960 , which is why columns (1) and (4) are labeled "1960-1963".
} 
past 50 years relative to the number of rooms in homes in other states. Perhaps regulations have been indirectly responsible for part of the slowing growth of California home sizes, and if they have that would in principle be a mechanism that other states or countries could replicate. Smaller homes do use less energy, but home size reduction has not been touted as an objective by proponents of energy efficiency regulations.

Begin by singling out one important characteristic, household size, in the seventh row of Table 6. In 1960 the average California house had 3.19 people living in it; by 2009 that had fallen to 3.03. During the same time period in other states household sizes fell from 3.43 to 2.67. Although household sizes fell everywhere, they fell more slowly in California. California went from having smaller household sizes than other states in 1960 to having larger household sizes in 2009, gaining 0.6 members per household.

California's growing relative household size matters because energy use per capita shrinks with household sizes. Examine Figure 5. While electricity use increases with the number of people in the home, it does so at a decreasing rate. As a consequence, electricity use per household member, or per capita, declines with household size. On average, an additional 0.6 household members in the RECS is associated with 1.9 fewer MBTUs of annual electricity use per household member. ${ }^{12}$ Recall from Table 2 that California's apparent savings, depicted in Figure 1, amount to 4.7 MBTUs per person. Household size alone, without accounting for any other demographic differences between California and other states, explains 40 percent of California's apparent savings. For non-electric energy, the household-size explanation is even larger. An additional 0.6 household members reduces non-electric energy use by 7.0 MBTUs per capita, or 81 percent of California's apparent savings of 8.6 MBTUs per capita.

Household size is only one of the demographic changes depicted in Table 6, and is certainly correlated with the others. To predict how all of the combined demographic changes combined affected residential energy use, I use the pooled 1993 through 2009 RECS to estimate a version of equation (1) in which the dependent variable is BTU per household member, and which includes additional demographic characteristics chosen to match those in Table 6: number of children, number of rooms and bedrooms, an indicator for owner occupation, and indicators for homes built pre-1950 and post-1980.

Table 7 presents results of this regression. Although the RECS contains information about many other household and demographic characteristics, in column (2) I limit the covariates to those available separately for California in the 1960 Census of Population and Housing, so that I can use the results to predict energy use changes over time due to the changing relative nature of California households. Key omitted variables include the size of the home in square feet and details about the home's energy-using appliances. To the extent those omitted variables are correlated with included measures such as the number of rooms in the home and the

\footnotetext{
${ }^{12}$ Based on a regression of energy per household member on a cubic in household size (plotted in Figure 5).
} 
household income, the included measures will help predict those changes as well. In other words, in Table 7 the "rooms" variable is correlated with higher energy use partly because houses with more rooms have more square feet of living space.

In general the coefficients in Table 7 conform to intuition. Household income increases electricity use at the mean levels of heating and cooling degree days. Large households use less energy per resident, and households with proportionally more kids use more energy per resident. Homes with more total rooms or proportionally more bedrooms use more energy. Older homes use less electricity.

In column (3) of Table 7 I add a slate of other home characteristics. The coefficients on the number of rooms and bedrooms shrink. Owner-occupancy is associated with more energy use in column (2), almost certainly because it is correlated with omitted home characteristics such as size in square feet, appliance use, and whether or not the home is an apartment. When other covariates are included in column (2) the coefficient on owner occupancy reverses becomes negative. This makes more intuitive sense, given that rental properties' tenants typically either don't pay their utility bills or don't choose their homes' appliances (Levinson and Neimann, 2004).

Table 8 combines the results in Table 7 with the relative changes in key household characteristics from Table 6. Real median household income in California fell by $\$ 11,408$ relative to other states over the past 50 years. At the mean heating and cooling degree days, this would result in "savings" of 31 thousand BTUs per household member - a small amount relative to the average electricity consumption of 16.5 million BTUs in the RECS, or relative to California's apparent savings of 4.7 million BTUs of residential electricity per capita reported at the top of the table. ${ }^{13}$ So California's apparent residential electricity savings are not an artifact of its relatively slower personal income growth. If income has anything to do with California's savings, it is because California's income growth has not translated into higher energy use the way it has in less temperate states, as documented in the previous section.

The number of people per household in California grew by 0.6 relative to other states. Using the coefficient in Table 7, this would result in a decline of 2509 thousand BTUs per household member - a significant fraction of average consumption and of California's apparent savings. In fact, this one demographic change alone explains nearly half of California's 4.7 million BTUs of apparent residential electricity savings per capita.

Together, the predicted effects of the long-term changes in household and home characteristics account for 2.9 million BTUs of residential electricity per household member -61 percent of California's apparent residential electricity savings. Without migration from the North to the Southwest, without accounting for California's temperate climate, and without any energy

\footnotetext{
1331 thousand BTUs is calculated from the coefficients on income and the interaction terms with HDD and CDD in Table 7: $31=-\$ 11.4 \times(-74.1+0.0077 \times 4830$ HDDs $+0.0316 \times 1248$ CDDs $)$.
} 
efficiency improvements, the predictions in Table 7 imply that the long-run changes in household and home characteristics explain the majority of the apparent energy savings documented in Table 2 and Figure 2 and promoted by pictures like Figure 1.

Putting the three parts of this together, Figure 1 looks like an artifact of changes having nothing to do with energy efficiency. Fifteen percent of the apparent electricity changes can be explained by the U.S. population shift to the Southwest, ignoring all of the other changing differences between Californian's and residents of other states. Another 20 percent can be attributed to the fact that nationwide income growth did less to increase energy demand in California's temperate climate, again ignoring all of the other changing differences. And a remaining 61 percent comes from a collection of demographic changes, such as California's rising relative household sizes, ignoring changing relative climates and household incomes.

It may be tempting to add the three parts together and say that 95 percent of California's apparent electricity savings can be explained by coincidental trends, but that would be inaccurate because the three parts interact. The comparison group, US states other than California, simultaneously shifted from the Northeast to the Southwest, experienced income growth resulting in more energy use, and underwent the demographic changes detailed in Table 6. We would like to estimate all of these effects simultaneously, to know how much each contributes to California's apparent energy savings holding constant the other concurrent changes.

Unfortunately, no data on energy use and household characteristics have been collected consistently back to the 1960s. At best we can use current data to estimate how much of the current differences between California and other states energy consumption results from observed differences in household characteristics having nothing to do with energy efficiency. The remainder may or may not be attributable to California's energy regulations, but at least the size of that remainder provides an upper bound on the share of the apparent energy savings that could possibly be attributed to efficiency rules. The analytical tool for such an exercise decomposing differences into those explained by observed characteristics and those possibly due to policy changes - was first described by Oaxaca (1973) and Blinder (1973).

\section{A Oaxaca-Blinder Decomposition of Residential Electricity Use in 2009}

The first step is to run two separate regressions of household electricity use per capita $(E)$ on household characteristics $(\boldsymbol{X})$ :

$$
\begin{gathered}
E_{C A}=\boldsymbol{X}^{\prime}{ }_{\boldsymbol{C} A} \boldsymbol{\beta}_{\boldsymbol{C A}}+\varepsilon_{C A} \\
E_{O}=\boldsymbol{X}^{\prime}{ }_{\boldsymbol{o}} \boldsymbol{\beta}_{\boldsymbol{o}}+\varepsilon_{o}
\end{gathered}
$$

where subscript $C A$ denotes data for households in California and subscript $O$ denotes data for households in other states. The goal is to explain the difference between the mean electricity consumption per capita in California and elsewhere: call that difference $\Delta \bar{E}=\bar{E}_{C A}-\bar{E}_{O}$. Using equations (2a) and (2b) we can decompose that difference as follows: 


$$
\Delta \bar{E}=\Delta X^{\prime} \beta_{O}+X_{C A}^{\prime} \Delta \beta
$$

The first term on the right is the part of the difference in electricity use explained by the difference in the household characteristics $(\Delta X)$. These characteristics include income, climate, home size, household composition, and other building features unrelated to energy efficiency. The first term thus indicates the portion of the difference between California and other states' energy use clearly not related to California's regulations. The second term is the part explained by the differences in the estimated parameters $(\Delta \beta)$. This might be due to energy efficiency, or some other unobserved characteristics of households that cause energy use to vary differently with observed characteristics in different regions.

Column (1) of Table 9 contains an estimate of equation (2a) - energy use for California households. Columns (2) and (3) of Table 9 contain estimates of equation (2b) - energy use for households in other states. The only difference between columns (2) and (3) is that the third column includes 26 regional fixed effects. ${ }^{14}$ Two particular features of the table stand out. First, there are large differences between the coefficients (the $\beta$ s) for California and for other states. And second, adding the regional fixed effects in column (3) does not have a dramatic effect on the $\beta$ s for other states, with the obvious exception of the climate variables HDD and CDD which are inherently regional.

Table 10 uses the coefficients in Table 9 to estimate versions of the Oaxaca-Blinder decomposition in equation (3). The difference in 2009 electricity consumption per capita in California and other states $(\Delta \bar{E})$ is 8,126 thousand BTUs. Most of that difference is due to underlying differences in the household characteristics between the two samples $(\Delta X)$. Without including the regional fixed effects, those observable characteristics explain 61 percent of the difference. When regional fixed effects are included, the observable characteristics explain 88 percent. Only 12 percent is left to be explained by differences in the coefficients $(\Delta \beta)$. This additional 12 percent includes other omitted household characteristics that are correlated with electricity use, are correlated with other included household characteristics, and differ between California and other states. One such variable might be energy efficiency. But at most, energy efficiency accounts for 12 percent of the 2009 difference between residential electricity consumption in California and other states.

In sum, the first part of this paper showed that California's relative decline in residential energy consumption per capita from 1963 to 2009 can largely be explained by factors unrelated to energy efficiency: the migration of the US population to hotter states; the smaller income elasticity of demand for electricity in California's mild climate; and relative changes in household characteristics, particularly household size. This part - the Oaxaca-Blinder decomposition - has shown that California's absolute difference in residential energy

\footnotetext{
${ }^{14}$ The 2009 RECS identifies 27 geographic regions - 16 large states including California and 11 clusters of smaller states.
} 
consumption per capita in 2009 can also largely be explained by household and regional characteristics unrelated to energy efficiency. Figure 1, held up by regulators, environmental advocacy groups, and the international development banks to demonstrate the efficacy of energy efficiency standards for buildings and appliances, demonstrates nothing of the kind. The vast majority of California's apparent conservation relative to the rest of the country comes from coincidental features of the geography and demographics. They have nothing to do with energy efficiency, are not replicable by other states or countries, and have no lessons for the rest of the world.

To be fair, this analysis does not mean that California's regulations have not been effective or beneficial. It simply means that figures like Figure 1 are uninformative as to those benefits. It might be, for example, that other US states and the US government quickly followed California's regulatory example, in which case we should not expect to find relative differences in electricity consumption per capita except those driven by geography and demographics. Also, as Figure 2 shows, residential electricity accounts for a relatively small part of California's overall energy use. Other sectors also saw per capita declines in California relative to other states. Two in particular, manufacturing and transportation, account for the majority of California's apparent savings. The next section briefly explores each of these.

\section{Other Sectors: Manufacturing and Transportation}

Although energy efficiency proponents point to residential electricity as the prime example of California's difference from other states, California's energy consumption per capita has been falling in every sector - residential, commercial, industrial, and transportation - and has been falling for both electricity and non-electric energy in each of those sectors. Figures similar

to Figure 1 can be drawn for each sector and energy type, and the line depicting California energy use per capita drops below the line for other states, though most sharply for residential electricity. Table 2 and Figure 2 summarize what those other figures would look like. Although residential electricity depicted in Figure 1 looks most impressive, the sector accounted for only 4 percent of California's energy consumption in 2009. Transportation and industrial energy use accounted for 39 and 20 percent, respectively, and so even though California's energy efficiency gains were smaller for those sectors in percentage terms, those two sectors contributed more to California's overall energy efficiency gains. This section examines industry and transportation in turn.

\section{Manufacturing: Scale and Economic Composition}

Skeptics have hypothesized that California's four-decade-long improvement in industrial energy efficiency stems from the changing scale and composition of California's economy relative to that of other U.S. states. In other words, California may be simply losing 
manufacturing, and especially energy-intensive manufacturing, at a faster rate than other states. One might even be concerned that the costs of complying with California regulations could be the cause of that shift. If California's regulations succeeded in reducing the state's energy demand by driving energy-intensive industries to relocate out-of-state or overseas, that would not be replicable in turn by other jurisdictions, and California's regulations would not provide a model for national or global energy conservation.

To address this, I turn to the Manufacturing Energy Consumption Survey (MECS), which has been conducted every three to four years from 1991 to 2006 by the Energy Information Administration. Figure 6 depicts how net electricity use has changed over that time for each 3digit North American Industrial Classification (NAICS) code. ${ }^{15,16}$ Not surprisingly, there is a wide variation across industries in electricity use per dollar of value added, and many industries show a large drop in electricity use. But these are national averages. The energy efficiency advocates would expect that energy use per dollar of value added will have fallen more in California than other states. The skeptics contend that California's manufacturing sector has simply shrunk in size or shifted away from the most energy-intensive industries, relative to other states.

To begin to assess those claims, Figure 7 plots the share of total manufacturing value added, in 1963 and 2009, for both California and other states. The pattern is similar. Both California and other states experienced large increases in petroleum and coal, chemicals, and electronics, and decreases in transport equipment, textiles and apparel. But the scale of the changes differ, leading to the possibility that industrial composition changes may have accounted for some of California's gains.

To separate the technological improvements from the composition changes, I combine the information in Figure 6 and Figure 7 to predict net electricity use in each year $\left(\hat{E}_{t}^{M}\right)$ based on each industry's value added in each year and the 1991 national electricity use per dollar of value added.

$$
\hat{E}_{t}^{M}=\sum_{i}\left(E_{i, 1991}^{M} / v_{i, 1991}\right) \times v_{i t}
$$

where the term in brackets is the average electricity use per dollar of value added by industry $i$ from the 1991 MECS as depicted in Figure 6, and $v_{i t}$ is the value added by industry $i$ in year $t$, from the Annual Survey of Manufactures (ASM). Subscripts $i$ refer to 3-digit NAICS codes. The calculation combines both the scale of the manufacturing sector and its composition.

Figure 8 plots equation (4) separately for California and other states, indexed so that 1963 equals 100. The results are dramatic. Over the past 5 decades, California's industrial electricity

\footnotetext{
${ }^{15}$ The comparison is made slightly difficult by the fact that the 1991 survey used Standard Industrial Classifications (SIC) codes. I converted SIC codes to NAICS codes using a cross-walk provided by the Census Bureau.

${ }^{16}$ I use "net" electricity use because some industries cogenerate electricity as part of their production.
} 
demand, as predicted by its size and composition, has grown as much or more than the rest of the nation. If anything, declines in electricity use by California industry have come in spite of the fact that the state's mix of industries is working against it.

Table 11 shows the details of the calculations in equation (4), combining information about the contemporaneous size of each industry and the energy intensity of that industry in each year. Food and beverage production grew 221 percent from 1963 to 2009 in California and 176 percent in other states. With no change in electricity use per dollar of value added, the industry's energy use would have grown more in California than in other states. But because California's population grew faster, food and beverage energy use per capita would have grown more slowly in California. The middle panel of Table 11 presents the weighted average of energy growth of all 3-digit NAICS codes, weighted by 1991 energy consumption. If every industry used its 1991 electricity consumption per dollar of value added in every year, electricity use by California manufacturers would have grown 350 percent and only 138 percent in other states. But California's population also grew faster, doubling since 1960 while other states grew by 50 percent. Conducting exactly the same experiment with per-capita rather than total energy use by each manufacturing sector, electricity use per capita would still have grown faster in California: by 115 percent in California and 51 percent in other states.

The rest of that middle panel presents the same calculations using non-electric industrial energy and the 2006 MECS, with no change in the underlying result. California's manufacturing industry would have shown faster growth of total and per capita energy consumption than other U.S. states had it not been for a change in energy use within each 3-digit NAICS code. Rather than explaining apparent energy efficiency gains from California manufacturers, the changing mix of industries enlarges it. Something other than the size and mix of industries must explain the savings shown in Figure 2 and Table 2.

\section{Intra-industry Composition}

Some of the observed energy efficiency gains may have come from true increases in energy efficiency, and some may come from intra-industry composition changes. Primary metals, for example, includes factories that produce aluminum from raw materials and pipes from purchased steel. Manufacturing aluminum uses far more energy, and to the extent that production in the broad primary metals category has shifted away from aluminum and towards pipes, energy consumption per dollar of value added will have declined, even without technological changes in energy efficiency.

To address this I need a measure of energy intensity more disaggregate than the 3-digit NAICS codes used in and Figure 7 and Figure 8. Recent versions of the ASM report net electricity use by six-digit NAICS code. These can be matched to the value added by each industry in California and other states using the four-digit SIC codes in the 1963 Census of Manufactures and the six-digit NAICS codes in the 2007 Census of Manufactures. 
The task of examining industry composition at this finer level of disaggregation is complicated for two reasons. First, the match between four-digit SIC codes and six-digit NAICS codes is not one-to-one. And second, some codes are not reported for California so as to protect confidential business information. Consequently, at the bottom of Table 11 I report the percentage growth two ways, with and without the unmatched industry codes. I assigned each industry its current net electricity use, from the 2009 ASM. If each industry had used its 2009 electricity intensity, electricity demand by manufacturers would have grown by 34 percent in states other than California, and by an astonishing 645 percent in California. California's faster population growth accounts for some of this. Dividing by population, other states' industrial electricity use per capita stayed flat or even shrank slightly, while California's grew by 264 or 333 percent, depending how I treat unmatched industry codes. Rather than revealing industrial composition changes favoring California that were hidden by the more aggregate analysis, this disaggregation shows that California's composition tilted even more towards electricity-using industries.

In sum, per capita energy used by California's manufacturing sector has declined relative to the energy used by other states' manufacturing. This has not been the result of California's manufacturing base shrinking relative to other states, nor has it been the result of California's industrial composition shifting to less energy-intensive products.

\section{Transport}

This sector is extremely simple, and this section can be correspondingly brief. Since 1966, motor fuel consumption per capita has grown by 12 percent in California and by 45 percent in other states. But California's relative savings are entirely explained by miles traveled rather than vehicle efficiency. California vehicles used 32 percent less fuel per mile driven in 2009 than in 1966, while other states' vehicles used 31 percent less. By contrast, California vehicles travelled 64 percent more miles per capita, while other states' vehicles traveled 111 percent more. California's apparent fuel savings come from other states' residents driving more, not California vehicles being more energy efficient.

Figure 9 plots California and other U.S. states' motor fuel consumption per capita, indexed so that 1966 equals 100 (the first year of the DOT data). The pattern looks similar to that in Figure 1, the same figure drawn for residential electricity. At the bottom of Figure 9 I have plotted the difference between the two lines, and transportation fuel use shows the same pattern, a steadily increasing gap between California and the rest of the country. What explains this gap? The dashed line plots the growth rate using California's vehicle miles traveled per capita, divided by the national average fuel economy (miles per gallon). In other words, the dashed line plots what the growth of California motor fuel use would have been had California vehicles had the national fuel economy rather than California fuel economy. None of the gains are explained by fuel economy; Californians simply increased their driving miles by less than residents of other states. 


\section{Conclusions: Regulations Did Not Cause California's Energy Savings Relative to Other States}

The poster-child for energy efficiency regulations is residential electricity. Although it only accounts for 4 percent of California's 2009 energy use, it exhibits the most dramatic difference between California's energy growth rate since 1963 and that in other states. It turns out, however, that most of those apparent savings can be explained by long run trends unrelated to energy efficiency. Fifteen percent comes from the migration of the U.S. population from the North to the Southwest. Twenty percent comes from California's low income-elasticity of energy demand that is a consequence of its mild climate. And nearly 60 percent of the apparent savings can be explained by differences in the way the demographics of California and other states have changed: household incomes, household sizes, home sizes, etc. Together, nearly 90 percent of the difference between California's residential electricity consumption in 2009 and that in other states can be explained by household and geographic differences unrelated to energy efficiency.

The largest share of energy consumption occurs in the transport sector, and here the energy efficiency gains are also illusory. All of them can be explained by a relative decline in miles driven by Californians. While that may be a worthy outcome, and may be driven by public policies such as fuel taxes or public transportation subsidies, it is not a consequence of energy efficiency. If there is a case to be made for California's energy efficiency gains, the strongest evidence comes from the industrial sector. Energy consumption by California's manufacturers has grown less quickly than in other states, despite the fact that the scale and composition of California's industries would suggest its energy use would have grown faster.

In the end, the findings here undermine Figure 1 as evidence in support of California's standards, but they do not show that those standards have not been effective or that they should not be tightened further or promoted elsewhere. All we can say is that pictures such as Figure 1 do not demonstrate those standards' efficacy. Even without California's regulations, its residential electricity consumption per capita would have been falling steadily relative to other U.S. states for the past 40 years. 


\section{References}

Allcott, Hunt and Michael Greenstone. 2012. "Is There an Energy Efficiency Gap?" NBER WP 17766.

Baker, David R. 2009. "California's energy efficiency an economic boon." SFGate.com (online version of San Francisco Chronicle). 26 January 2009.

Blinder, Alan. S. 1973. "Wage discimination: Reduced form and structural estimates." Journal of Human Resources 8: 436-455.

Brounen, Dirk , Nils Kok and John M. Quigley. 2012. "Residential Energy Use and Conservation: Economics and Demographics" California Center for Energy and Environmental Economics Working Paper WP-036, University of California, Berkeley.

California Air Resources Board (CARB). 2008. "Climate Change Scoping Plan" (http://www.arb.ca.gov)

California Public Utilities Commission and California Energy Commission. 2006. "Energy Efficiency: California's Highest-Priority Resource" June 2006.

California Public Utility Commission. 2011. "California's Long-Term Energy Efficiency Strategic Plan" (http://www.cpuc.ca.gov)

Cebula, Richard J. and Nate Herder. 2010. "An Empirical Analysis of Determinants of Commercial and Industrial Electricity Consumption" Business and Economics Journal, Volume 2010: BEJ-7, March 6.

Clemente, Jude. 2011. " Is California's Electricity Policy Really a Model for the United States?" Innovative Energy Policies Vol. 1 (2011), pp. 1-6.

Costa, Dora L. and Matthew E. Kahn. 2010. "Why Has California's Residential Electricity Consumption Been So Flat since the 1980's: A Microeconometric Approach." NBER Working Paper 15978.

Ettenson, Lara. 2011. "Energy efficiency: California's leading energy resource." Electric Light and Power. November 9, 2011.

Galbraith, Kate. 2009a. "Deciphering California's Efficiency Successes" New York Times. 14 April 2009.

Galbraith, Kate. 2009b. "California Unveils TV Efficiency Standards." New York Times. 18 September 2009. 
Kandel, Adrienne, Margaret Sheridan and Patrick McAuliff. 2008. "A Comparison of Per Capita Electricity Consumption in the United States and California." Staff Paper-California Energy Commission. August 2008.

Kaufman, Noah and Palmer, Karen. 2010. "Energy-Efficiency Program Evaluations: Opportunities for Learning and Inputs to Incentive Mechanisms." Resources For the Future Discussion Paper 10-16. April 2010.

Levinson, Arik and Scott Niemann. 2004. "Energy Use by Apartment Tenants When Landlords Pay for Utilities," Resource and Energy Economics, 26(1) 51-75.

Massachusetts Secretary of Energy and Environmental Affairs. 2010. "Massachusetts Clean Energy and Climate Plan for 2020: A report to the Great and General Court pursuant to the Global Warming Solutions Act" (www.mass.gov/eea/)

Metcalf, Gilbert E. 2008. "An Empirical Analysis of Energy Intensity and Its Determinants at the State Level," The Energy Journal 29(3): 1-26.

Mitchell, Cynthia, Reuben Deumling, and Gill Court. 2009. "Stabilizing California's Demand: The Real Reasons Behind the State's Energy Savings" Public Utilities Fortnightly 147, March, 50-62.

Oaxaca, Ronald L. 1973. "Male-female wage differentials in urban labor markets." Internationa Economic Review 14: 693-709.

Roland-Holst, David. 2008. "Energy Efficiency, Innovation, and Job Creation in California." Department of Agricultural and Resource Economics, University of California Berkeley. October 2008.

Rosenfeld, Arthur H. and Deborah Poskanzer. 2009. "A Graph Is Worth a Thousand GigawattHours: How California Came to Lead the United States in Energy Efficiency" Innovations. Fall 57-79.

Sudarshan, Anant. 2010. "Deconstructing the 'Rosenfeld Curve': Why is Per Capita Residential Energy Consumption in California so Low? " US Association for Energy Economics Working Paper 10-063.

Tanton, Thomas. 2008. "California's Energy Policy: A Cautionary Tale for the Nation" Competitive Enterprise Institute. Washington DC.

U.S. Department of Energy. 2009 "An Investigation into California's Residential Energy Consumption." 29 July 2009.

U.S. Environmental Protection Agency (EPA). 2011. 2011 U.S. Greenhouse Gas Inventory Report. (April 2011) USEPA \#430-R-11-005. 
Table 1: California Energy Policies

\begin{tabular}{lll}
\hline Warren Alquist Act & $\begin{array}{l}\text { Established the California Energy Commission (CEC) } \\
\text { with authority to regulate appliances and (later) } \\
\text { buildings. }\end{array}$ & 1974 \\
Title 20 & $\begin{array}{l}\text { First appliance standards in the US. } \\
\text { Title 24 }\end{array}$ & 1976 \\
Fecoupling natural gas profits from sales. & 1978 \\
Decoupling electric utility profits from power sales. & 1978 \\
AB 1890 & $\begin{array}{l}\text { Restructuring of electricity industry, mandated } \\
\text { investment in public benefit programs. }\end{array}$ \\
AB 32 & Global Warming Solutions Act & 1996
\end{tabular}

Source: Roland-Holst (2008) 
Table 2: California per Capita Energy Savings

Relative to Other US States 1963-2009

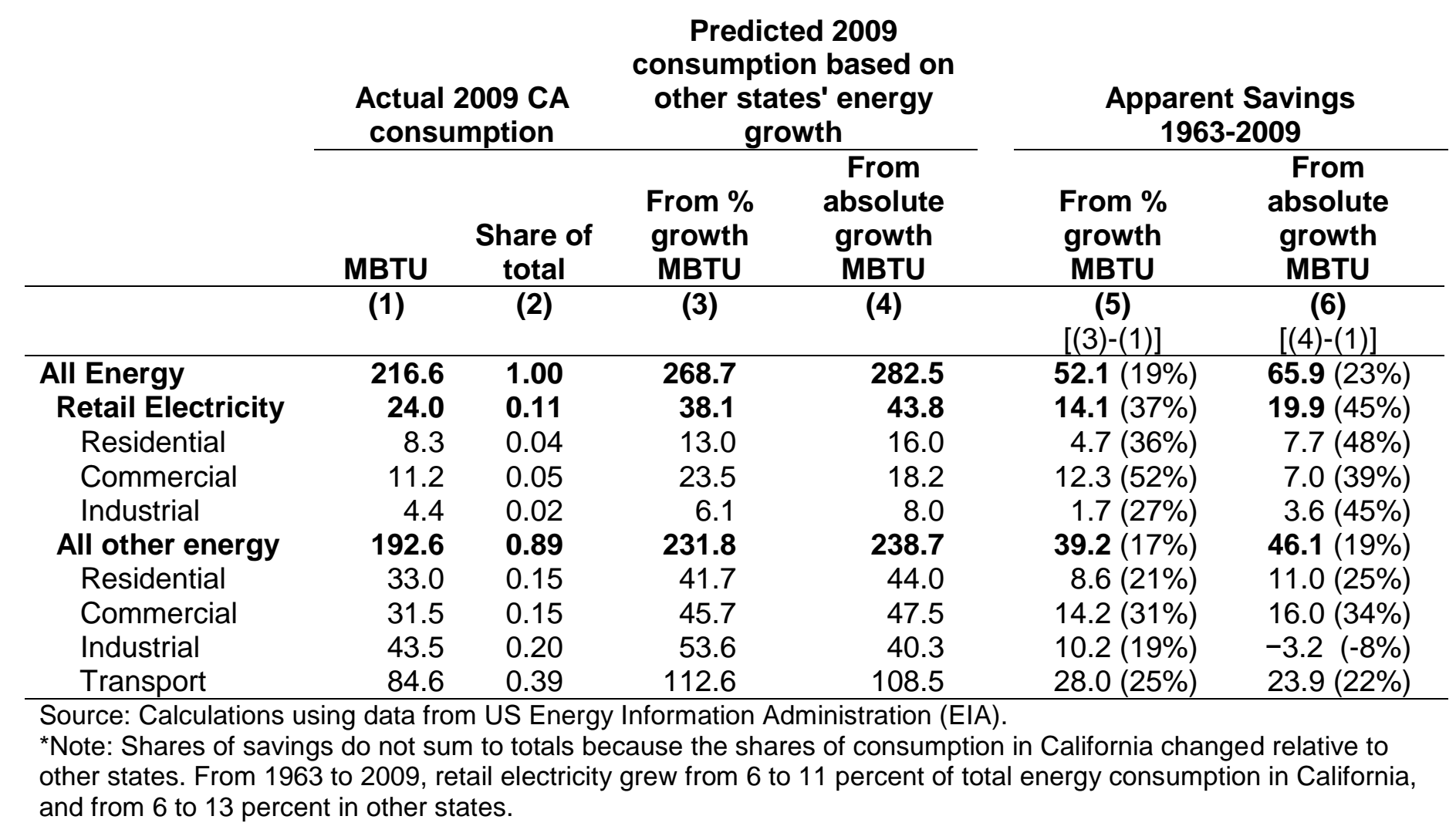


Table 3: Population Shifts and Energy Consumption per Capita

1963-2009

\begin{tabular}{|c|c|c|c|c|c|c|}
\hline & \multicolumn{2}{|c|}{$\begin{array}{c}\text { Other States' Energy } \\
\text { Growth }\end{array}$} & \multirow{2}{*}{$\begin{array}{c}\text { Difference without } \\
\text { Migration } \\
\text { MBTU } \\
\end{array}$} & \multicolumn{2}{|c|}{$\begin{array}{l}\text { Share of Savings from } \\
\text { Columns (5) and (6) of Table } 2^{*}\end{array}$} & \multirow{2}{*}{$\begin{array}{c}\text { Correlation(state } \\
\text { population growth, } \\
\text { average energy per } \\
\text { capita) }\end{array}$} \\
\hline & MBTU & $\%$ & & $\begin{array}{l}\text { From \% } \\
\text { change }\end{array}$ & $\begin{array}{l}\text { From absolute } \\
\text { difference }\end{array}$ & \\
\hline & $(1)$ & (2) & $(3)$ & $(4)$ & (5) & (6) \\
\hline \multicolumn{7}{|l|}{ Residential } \\
\hline Electricity & 11.5 & 248.9 & 0.70 & 0.15 & 0.09 & 0.093 \\
\hline Other energy & 6.4 & 12.9 & -1.28 & -0.15 & -0.12 & -0.418 \\
\hline \multicolumn{7}{|l|}{ Commercial } \\
\hline Electricity & 11.6 & 336.7 & 0.21 & 0.02 & 0.03 & 0.039 \\
\hline Other energy & 21.3 & 88.1 & -1.00 & -0.07 & -0.06 & -0.205 \\
\hline
\end{tabular}


Table 4: Household Electricity Consumption per Household Member Predicted by Climate and Income

Dependent variable:

1000 BTUs per person

Means Coefficients

HDD

4,338

(2)

CDD

$(1,647)$

1,363

0.08

CDD

(663)

Household income

53.1

(\$1000s 2010)

HDD $\times$ income

(37.2)

(0.12)

$4.73^{*}$

(0.30)

$-52.0^{*}$

(13.1)

$0.0112^{*}$

CDD $\times$ income

(0.0018)

$0.0386^{*}$

Household size

2.66

(1.49)

$(0.0045)$

Trend

$-3,510^{*}$

(44)

139 *

(10)

Constant

$11,073^{*}$

$(1,018)$

\begin{tabular}{lcc}
\hline $\begin{array}{l}\text { Mean and std. dev. of } \\
\text { dependent variable }\end{array}$ & 16,530 & \\
\hline Observations $=34,292$ & $(12,888)$ & \\
\hline Marginal effects & $\mathrm{R}^{2}=0.24$ \\
\hline Income at mean HDD and CDD & 49.2 \\
HDD at mean income & 0.68 \\
CDD at mean income & 6.8 \\
\hline
\end{tabular}

Robust standard errors in parentheses.

*Statistically significant at 5 percent.

Source: Residential Energy Consumption Surveys: 1993, 1997, 2001, 2005, 2009. 
Table 5: Predicted Increase in Residential Electricity per Capita

From a \$1000 Increase in Household Income (2010 dollars)

\begin{tabular}{lccc} 
& $\begin{array}{c}\text { Average } \\
\text { HDD }\end{array}$ & $\begin{array}{c}\text { Average } \\
\text { CDD }\end{array}$ & $\begin{array}{c}\text { Predicted Electricity Increase } \\
\text { (1000 BTUs / person) }\end{array}$ \\
\cline { 2 - 4 } & $(1)$ & $(2)$ & $(3)$ \\
\cline { 2 - 4 } California & 2,601 & 901 & 11.9 \\
Other states & 4,830 & 1,248 & $\underline{50.2}$ \\
$\quad$ absolute diff (1000 BTUs/capita) & & & 38.4 \\
Difference for a \$25,000 income & & & 959.0 \\
increase & & & $20.4 \%$ \\
Share of apparent 4.7 MBTU savings & & & \\
\hline
\end{tabular}

Uses regression coefficients in Table 4. 
Table 6: Housing, Climate, and Household Characteristics

\begin{tabular}{|c|c|c|c|c|c|c|c|c|}
\hline & \multicolumn{3}{|c|}{ California } & \multicolumn{3}{|c|}{ Other US States } & \multirow{2}{*}{$\begin{array}{c}\text { CA change } \\
\text { relative to } \\
\text { other states }\end{array}$} & \multirow{2}{*}{$\begin{array}{c}\text { RECS } \\
\text { averages } \\
1993-2009\end{array}$} \\
\hline & $1960-1963$ & 2009 & Change & $1960-1963$ & 2009 & Change & & \\
\hline & $(1)$ & $(2)$ & (3) & (4) & $(5)$ & $(6)$ & $(7)$ & $(8)$ \\
\hline $\begin{array}{l}\text { Residential electricity per } \\
\text { capita }^{9} \text { (MBTU) }\end{array}$ & 3.76 & 8.29 & +4.53 & 4.98 & 17.21 & +12.22 & -7.70 & 16.5 \\
\hline $\begin{array}{l}\text { Residential other energy } \\
\text { per capita }{ }^{\mathrm{g}} \text { (MBTU) }\end{array}$ & 35.56 & 33.03 & -3.53 & 53.21 & 60.65 & +7.44 & -10.97 & 38.3 \\
\hline Population (1000s) ${ }^{\mathrm{a}}$ & 17,668 & 36,962 & $+109 \%$ & 171,632 & 270,521 & $+58 \%$ & $+51 \%$ & \\
\hline $\begin{array}{l}\text { Real income per capita } \\
(\$ 2010)^{\mathrm{a}}\end{array}$ & $\$ 16,102$ & $\$ 38,834$ & $+141 \%$ & $\$ 12,853$ & $\$ 35,091$ & $+173 \%$ & $-32 \%$ & $\$ 24,161$ \\
\hline $\begin{array}{l}\text { Real median household } \\
\text { income }(\$ 2010)^{\dagger}\end{array}$ & 40,716 & 57,718 & $\begin{array}{c}+\$ 17,002 \\
(41.8 \%)\end{array}$ & 37,723 & 63,133 & $\begin{array}{c}+\$ 28,410 \\
(81.8 \%)\end{array}$ & $\begin{array}{c}-\$ 11,408 \\
(-26 \%)\end{array}$ & $\$ 43,197$ \\
\hline $\begin{array}{l}\text { Occupied housing units } \\
(1000 \mathrm{~s})^{\mathrm{b}}\end{array}$ & 4,982 & 12,215 & $+145 \%$ & 48,042 & 101,401 & $+111 \%$ & $+34 \%$ & \\
\hline Household size $\mathrm{b}^{\mathrm{b}, \mathrm{c}}$ & 3.19 & 3.03 & -0.16 & 3.43 & 2.67 & -0.76 & +0.60 & 2.66 \\
\hline Rooms per house ${ }^{b}$ & 4.49 & 5.20 & +0.71 & 4.90 & 5.67 & +0.77 & -0.06 & 5.74 \\
\hline Bedrooms per house ${ }^{b}$ & 2.05 & 2.58 & +0.53 & 2.26 & 2.70 & +0.44 & +0.08 & 2.72 \\
\hline Built pre-1950 & 0.600 & 0.305 & -0.295 & 0.738 & 0.312 & -0.426 & +0.131 & 0.230 \\
\hline Built post- $1980^{\circ}$ & - & 0.369 & - & - & 0.417 & - & -0.048 & 0.348 \\
\hline Owner occupied ${ }^{\mathrm{b}}$ & 0.584 & 0.566 & -0.018 & 0.622 & 0.670 & +0.048 & -0.066 & 0.671 \\
\hline Kids $<14^{d}$ & 0.956 & 0.624 & -0.332 & 1.092 & 0.535 & -0.557 & +0.225 & 0.540 \\
\hline $\begin{array}{l}\text { Cooling degree days } \\
\text { (population wtd avg) }\end{array}$ & 901 & 901 & - & 1145 & 1349 & $+17.8 \%$ & $+17.8 \%$ & 1363 \\
\hline $\begin{array}{l}\text { Heating degree days } \\
\text { (population wtd avg) }\end{array}$ & 2601 & 2601 & - & 5066 & 4609 & $-9.0 \%$ & $-9.0 \%$ & 4337 \\
\hline \multicolumn{9}{|c|}{ 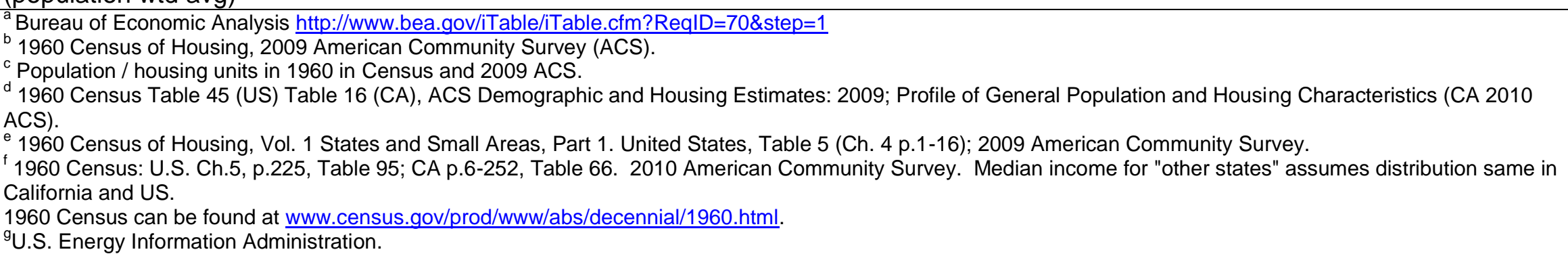 } \\
\hline
\end{tabular}




\section{Table 7: Residential Energy Use per Household Member}

\begin{tabular}{|c|c|c|c|}
\hline \multirow[b]{2}{*}{$\begin{array}{l}\text { Dependent variable: } 1000 \\
\text { BTUs per capita }\end{array}$} & \multirow[b]{2}{*}{ Means } & \multicolumn{2}{|c|}{ Regression Coefficients } \\
\hline & & $\begin{array}{l}\text { Census } \\
\text { Variables }\end{array}$ & $\begin{array}{c}\text { Other RECS } \\
\text { variables }\end{array}$ \\
\hline & (1) & (2) & (3) \\
\hline \multirow[t]{2}{*}{ HDD } & 4,326 & 0.040 & -0.17 \\
\hline & $(2,275)$ & $(0.12)$ & $(0.11)$ \\
\hline \multirow[t]{2}{*}{ CDD } & 1,371 & $4.03^{*}$ & $2.95^{\star}$ \\
\hline & $(1,037)$ & $(0.28)$ & $(0.27)$ \\
\hline \multirow{3}{*}{$\begin{array}{l}\text { Household income } \\
(\$ 1000 \text { s 2010) }\end{array}$} & 54.4 & $-74.1^{*}$ & $-64.9^{*}$ \\
\hline & $(37.4)$ & $(12.6)$ & $(12.0)$ \\
\hline & & $0.0077^{*}$ & $0.0045^{*}$ \\
\hline HDD $\times$ income & & $(0.0017)$ & $(0.0016)$ \\
\hline \multirow[t]{2}{*}{ CDD $\times$ income } & & $0.0316^{*}$ & $0.0249^{*}$ \\
\hline & & $(0.0042)$ & $(0.0041)$ \\
\hline \multirow[t]{2}{*}{ Household size } & 2.75 & $-4,182^{*}$ & $-4,259^{*}$ \\
\hline & $(1.49)$ & (69) & $(73)$ \\
\hline \multirow[t]{2}{*}{ Kids } & 0.54 & $451^{*}$ & $501^{*}$ \\
\hline & $(0.96)$ & (68) & $(70)$ \\
\hline \multirow[t]{2}{*}{ Rooms } & 5.80 & $1,172^{*}$ & $647^{*}$ \\
\hline & $(2.00)$ & (95) & $(95)$ \\
\hline \multirow[t]{2}{*}{ Bedrooms } & 2.76 & $885^{*}$ & $333^{*}$ \\
\hline & $(1.05)$ & $(135)$ & $(129)$ \\
\hline \multirow[t]{2}{*}{ Owner Occupied } & 0.67 & $1,888^{*}$ & $-668^{*}$ \\
\hline & & (149) & $(167)$ \\
\hline \multirow[t]{2}{*}{ Built pre 1950} & 0.22 & $-2,018^{*}$ & $-774^{*}$ \\
\hline & & (153) & $(151)$ \\
\hline \multirow[t]{2}{*}{ Built post 1980} & 0.36 & $928^{*}$ & $-502^{*}$ \\
\hline & & $(135)$ & $(140)$ \\
\hline \multirow[t]{2}{*}{ Trend $(1963=1)$} & 39.3 & $91.7^{*}$ & $20.0^{*}$ \\
\hline & $(6.4)$ & $(9.2)$ & $(9.1)$ \\
\hline \multirow{2}{*}{\multicolumn{2}{|c|}{$\begin{array}{l}\text { Rural, seniors, size, type, } \\
\text { dishwasher, clothes washer, } \\
\text { dryer, TVs, AC, pool }\end{array}$}} & & \\
\hline & & no & yes \\
\hline \multirow[t]{2}{*}{ Constant } & & $7,750^{*}$ & $12,855^{\star}$ \\
\hline & & $(964)$ & (965) \\
\hline $\begin{array}{l}\text { Mean and std. dev. of } \\
\text { dependent variable }\end{array}$ & $\begin{array}{c}16,257 \\
(12,592)\end{array}$ & & \\
\hline Observations $=32,352$ & & $\mathrm{R}^{2}=0.32$ & $R^{2}=0.38$ \\
\hline
\end{tabular}


Table 8: California Residential Energy Savings -- 1960-2009

\begin{tabular}{lccc} 
& & \multicolumn{2}{c}{ Electricity } \\
\cline { 3 - 4 } Household characteristic & Average & Coeff. from Table 7 & $\begin{array}{c}\text { Predicted change } \\
\text { (1000 BTUs) }\end{array}$ \\
\hline & $\mathbf{( 1 )}$ & $\mathbf{( 2 )}$ & $\mathbf{( 3 )}$ \\
\hline (1) ElA Data & 11,374 & & $-4,705$ \\
\hline Electricity /capita (1000 BTU) & & & -31 \\
\hline (2) RECS Data and Predictions & $-\$ 11,408$ & $2.7^{\text {a }}$ & $-2,509$ \\
\hline Real median household income (\$2010) & & & -70 \\
Household size & +0.60 & $-3,823$ & +71 \\
Rooms per house & -0.06 & 994 & -264 \\
Bedrooms per house & +0.08 & 780 & -45 \\
Built pre-1950 & +0.131 & $-2,287$ & -125 \\
Built post-1980 & -0.048 & 585 & 101 \\
Owner occupied & -0.066 & 1,679 & 394 \\
Kids < 14 & +0.225 & & $-2,871$ \\
Total Explained by Table 7 Regressions & & & \\
\hline
\end{tabular}

Percent of apparent savings explained by regressions [(1)/(2)]

$61 \%$

${ }^{a}$ The coefficient on income includes the coefficient on interactions with HDD and CDD in Table 7, multiplied by the means of HDD and CDD. 
Table 9: Predicted Electricity per Household Member - 2009

\begin{tabular}{|c|c|c|c|}
\hline \multirow{3}{*}{$\begin{array}{l}\text { Dependent variable: } 1000 \\
\text { BTUs per household member }\end{array}$} & \multicolumn{3}{|c|}{ Regression Coefficients } \\
\hline & CA & $\begin{array}{l}\text { Other } \\
\text { States }\end{array}$ & $\begin{array}{c}\text { Other with } 26 \\
\text { regional fixed } \\
\text { effects }\end{array}$ \\
\hline & $(1)$ & $(2)$ & (3) \\
\hline HDD & $\begin{array}{c}0.345 \\
(0.426)\end{array}$ & $\begin{array}{l}-0.585^{\star} \\
(0.233)\end{array}$ & $\begin{array}{c}0.257 \\
(0.265)\end{array}$ \\
\hline CDD & 0.678 & -0.613 & 0.400 \\
\hline & $(0.789)$ & $(0.491)$ & $(0.537)$ \\
\hline $\begin{array}{l}\text { Household income } \\
(\$ 1000 \text { s 2010) }\end{array}$ & $\begin{array}{l}-21.9 \\
(26.9)\end{array}$ & $\begin{array}{l}-35.3 \\
(26.3)\end{array}$ & $\begin{array}{l}-27.37 \\
(26.48)\end{array}$ \\
\hline HDD $\times$ income & $\begin{array}{l}-0.0074 \\
(0.0072)\end{array}$ & $\begin{array}{c}0.0014 \\
(0.0035)\end{array}$ & $\begin{array}{l}0.0011 \\
(0.0035)\end{array}$ \\
\hline CDD $\times$ income & $\begin{array}{r}0.0403^{*} \\
(0.0186)\end{array}$ & $\begin{array}{r}0.0155^{\star} \\
(0.0074)\end{array}$ & $\begin{array}{c}0.0134 \\
(0.0074)\end{array}$ \\
\hline Household size & $\begin{array}{r}-2,552^{*} \\
(181)\end{array}$ & $\begin{array}{r}-5,215^{\star} \\
(137)\end{array}$ & $\begin{array}{r}-5,211^{*} \\
(137)\end{array}$ \\
\hline Rural & $\begin{array}{r}4,543^{*} \\
(1,333)\end{array}$ & $\begin{array}{r}2,705^{*} \\
(292)\end{array}$ & $\begin{array}{r}2,424^{*} \\
(298)\end{array}$ \\
\hline Kids & $\begin{array}{r}432^{*} \\
(214)\end{array}$ & $\begin{array}{r}860^{*} \\
(137)\end{array}$ & $\begin{array}{l}821^{*} \\
(136)\end{array}$ \\
\hline Seniors & $\begin{array}{l}720 \\
(382)\end{array}$ & $\begin{array}{l}-651^{*} \\
(180)\end{array}$ & $\begin{array}{l}-571^{*} \\
(179)\end{array}$ \\
\hline Total square feet & $\begin{array}{l}2.24^{*} \\
(0.68)\end{array}$ & $\begin{array}{r}0.797^{*} \\
(0.128)\end{array}$ & $\begin{array}{r}0.914^{*} \\
(0.129)\end{array}$ \\
\hline Rooms & $\begin{array}{l}178 \\
(204)\end{array}$ & $\begin{array}{l}767^{*} \\
(190)\end{array}$ & $\begin{array}{r}719^{*} \\
(190)\end{array}$ \\
\hline Bedrooms & $\begin{array}{l}-821 \\
(429)\end{array}$ & $\begin{array}{r}582^{*} \\
(236)\end{array}$ & $\begin{array}{l}597^{*} \\
(235)\end{array}$ \\
\hline Mobile home & $\begin{array}{c}105 \\
(1,042)\end{array}$ & $\begin{array}{r}1,621^{*} \\
(550)\end{array}$ & $\begin{array}{r}1,948^{*} \\
(542)\end{array}$ \\
\hline Attached & $\begin{array}{c}92 \\
(590)\end{array}$ & $\begin{array}{r}-1,590^{*} \\
(355)\end{array}$ & $\begin{array}{r}-1,244^{*} \\
(373)\end{array}$ \\
\hline Apt bldg $<5$ units & $\begin{array}{l}-515 \\
(572)\end{array}$ & $\begin{array}{r}-2,640^{*} \\
(449)\end{array}$ & $\begin{array}{r}-1,868^{*} \\
(461)\end{array}$ \\
\hline Apt bldg. $>=5$ units & $\begin{array}{l}-853 \\
(606)\end{array}$ & $\begin{array}{r}-3,739^{*} \\
(449)\end{array}$ & $\begin{array}{r}-3,169^{*} \\
(465)\end{array}$ \\
\hline Owner occupied & $\begin{array}{l}-282 \\
(454)\end{array}$ & $\begin{array}{l}-555 \\
(304) \\
\end{array}$ & $\begin{array}{l}-359 \\
(299)\end{array}$ \\
\hline
\end{tabular}

(continued) 
(Table 1, continued)

\begin{tabular}{|c|c|c|c|}
\hline Built 1950s & $\begin{array}{l}-456 \\
(611)\end{array}$ & $\begin{array}{l}-681 \\
(349)\end{array}$ & $\begin{array}{l}-797^{*} \\
(347)\end{array}$ \\
\hline Built 1960s & -450 & -84 & -371 \\
\hline Built 1970s & $\begin{array}{l}-738 \\
(595)\end{array}$ & $\begin{array}{l}-177 \\
(384)\end{array}$ & $\begin{array}{l}-491 \\
(394)\end{array}$ \\
\hline Built 1980s & $\begin{array}{r}-1,559^{*} \\
(649)\end{array}$ & $\begin{array}{l}-687 \\
(390)\end{array}$ & $\begin{array}{l}-940^{*} \\
(399)\end{array}$ \\
\hline Built 1990s & $\begin{array}{r}-1,338 \\
(696)\end{array}$ & $\begin{array}{l}-826^{*} \\
(414)\end{array}$ & $\begin{array}{r}-1,274^{*} \\
(428)\end{array}$ \\
\hline Built 2000s & $\begin{array}{c}-54 \\
(1,206)\end{array}$ & $\begin{array}{r}-2,758^{*} \\
(429)\end{array}$ & $\begin{array}{r}-3,190^{*} \\
(445)\end{array}$ \\
\hline Dishwasher & $\begin{array}{r}891^{*} \\
(371)\end{array}$ & $\begin{array}{r}680^{*} \\
(247)\end{array}$ & $\begin{array}{r}826^{*} \\
(250)\end{array}$ \\
\hline Clothes washer & $\begin{array}{l}712 \\
(809)\end{array}$ & $\begin{array}{r}-1,345^{*} \\
(525)\end{array}$ & $\begin{array}{r}-1,278^{*} \\
(522)\end{array}$ \\
\hline Dryer & $\begin{array}{l}252 \\
(760)\end{array}$ & $\begin{array}{r}2,457^{*} \\
(489)\end{array}$ & $\begin{array}{r}2,181^{*} \\
(491)\end{array}$ \\
\hline TV sets & $\begin{array}{r}1,093^{*} \\
(186)\end{array}$ & $\begin{array}{r}762^{*} \\
(96)\end{array}$ & $\begin{array}{r}797^{*} \\
(95)\end{array}$ \\
\hline Air conditioned & $\begin{array}{c}392 \\
(471)\end{array}$ & $\begin{array}{r}1,182^{*} \\
(313)\end{array}$ & $\begin{array}{r}1,460^{*} \\
(323)\end{array}$ \\
\hline Central air & $\begin{array}{c}-38 \\
(566)\end{array}$ & $\begin{array}{r}1,406^{*} \\
(267)\end{array}$ & $\begin{array}{r}618^{*} \\
(289)\end{array}$ \\
\hline Swimming pool & $\begin{array}{r}3,775^{*} \\
(783)\end{array}$ & $\begin{array}{r}5,009^{*} \\
(509)\end{array}$ & $\begin{array}{r}5,569^{*} \\
(505)\end{array}$ \\
\hline Stove/oven electric & $\begin{array}{r}816^{*} \\
(379)\end{array}$ & $\begin{array}{l}788.6^{*} \\
(220)\end{array}$ & $\begin{array}{r}877^{*} \\
(232)\end{array}$ \\
\hline Stove electric & $\begin{array}{r}860 \\
(1,006)\end{array}$ & $\begin{array}{l}-141.5 \\
(752)\end{array}$ & $\begin{array}{l}-331 \\
(743)\end{array}$ \\
\hline Oven electric & $\begin{array}{c}-39 \\
(1,060)\end{array}$ & $\begin{array}{r}3,349^{*} \\
(619)\end{array}$ & $\begin{array}{r}3,271^{*} \\
(609)\end{array}$ \\
\hline Heat electric & $\begin{array}{r}1,590^{*} \\
(452)\end{array}$ & $\begin{array}{r}6,430^{*} \\
(311)\end{array}$ & $\begin{array}{r}6,203^{*} \\
(308)\end{array}$ \\
\hline Water electric & $\begin{array}{r}3,656^{*} \\
(987)\end{array}$ & $\begin{array}{r}4,132^{*} \\
(261)\end{array}$ & $\begin{array}{r}4,081^{*} \\
(263)\end{array}$ \\
\hline 26 region fixed effects & no & no & yes \\
\hline Constant & $\begin{array}{r}8,016^{*} \\
(1,844)\end{array}$ & $\begin{array}{l}18,712^{*} \\
(1,959)\end{array}$ & $\begin{array}{r}12,519^{\star} \\
(2,169)\end{array}$ \\
\hline $\begin{array}{l}\text { Observations } \\
\text { R-squared }\end{array}$ & $\begin{array}{c}1,606 \\
0.50\end{array}$ & $\begin{array}{c}10,477 \\
0.48\end{array}$ & $\begin{array}{c}10,477 \\
0.49 \\
\end{array}$ \\
\hline
\end{tabular}

Standard errors in parentheses.

*Statistically significant at 5 percent.

Source: 2009 Residential Energy Consumption Survey. 
Table 10: Decomposition of Electricity Differences - 2009

\section{Average Electricity Use per}

Household Member (1000 BTUs)

\begin{tabular}{lr} 
California & 10,396 \\
Other States & 18,522 \\
Difference & 8,126 \\
\hline
\end{tabular}

\section{Oaxaca-Blinder Decomposition}

Without regional fixed effects

Explained $\left(\triangle X^{\prime} \beta\right)$

Unexplained $\left(X^{\prime} \Delta \beta\right)$
4,925

3,200

$61 \%$

$39 \%$

With 26 regional fixed effects

Explained $\left(\Delta X^{\prime} \beta\right)$

Unexplained $\left(X^{\prime} \Delta \beta\right)$
7,158

967
$88 \%$

$12 \%$

Source: 2009 Residential Energy Consumption Survey and calculations from Table 9. 


\section{Table 11: Predicted Manufacturing Energy Growth: 1963-2009}

\begin{tabular}{lrrrrr} 
& \multicolumn{2}{c}{ Predicted energy use } & & \multicolumn{2}{c}{ Per capita } \\
\cline { 2 - 3 } \cline { 5 - 6 } Electricity Use based on 1991 MECS & California & Other States & & California & Other States \\
\hline $311 / 312$ food/beverage/tobacco & $221 \%$ & $176 \%$ & & $53 \%$ & $75 \%$ \\
$313 / 314$ textiles & $153 \%$ & $-18 \%$ & & $21 \%$ & $-48 \%$ \\
$315 / 316$ apparel/leather & $249 \%$ & $-65 \%$ & & $67 \%$ & $-78 \%$ \\
321 wood & $-26 \%$ & $58 \%$ & & $-65 \%$ & $0 \%$ \\
322 paper & $188 \%$ & $169 \%$ & & $38 \%$ & $70 \%$ \\
323 printing & $21 \%$ & $13 \%$ & & $-42 \%$ & $-28 \%$ \\
324 petroleum/coal & $2558 \%$ & $1480 \%$ & & $1170 \%$ & $900 \%$ \\
325 chemicals & $947 \%$ & $346 \%$ & & $401 \%$ & $182 \%$ \\
326 plastic/rubber & $301 \%$ & $269 \%$ & & $92 \%$ & $134 \%$ \\
327 nonmetal minerals & $63 \%$ & $89 \%$ & & $-22 \%$ & $20 \%$ \\
331 primary metal & $19 \%$ & $6 \%$ & & $-43 \%$ & $-33 \%$ \\
332 fabricated metal & $276 \%$ & $202 \%$ & & $80 \%$ & $91 \%$ \\
333 machinery & $229 \%$ & $223 \%$ & & $57 \%$ & $104 \%$ \\
$334 / 335$ electronics & $605 \%$ & $216 \%$ & & $237 \%$ & $100 \%$ \\
336 transport equip & $47 \%$ & $82 \%$ & & $-30 \%$ & $15 \%$ \\
337 furniture & $136 \%$ & $176 \%$ & & $13 \%$ & $75 \%$ \\
339 miscellaneous & $1160 \%$ & $406 \%$ & $502 \%$ & $221 \%$
\end{tabular}

Weighted Average of All Manufacturing

$\begin{array}{lrrrr}\text { Electricity based on 1991 MECS } & 350 \% & 138 \% & 115 \% & 51 \% \\ \text { Non-electric Energy, 1991 MECS } & 1125 \% & 427 \% & 486 \% & 234 \% \\ \text { Electricity based on 2006 MECS } & 243 \% & 122 \% & 64 \% & 40 \% \\ \text { Non-electric Energy, 2006 MECS } & 669 \% & 244 \% & 267 \% & 118 \%\end{array}$

\section{Electricity Use 1963-2007 Based on 6-digit NAICS Codes in 2009 ASM}

$\begin{array}{lllll}\text { Ignoring missing industry codes } & 645 \% & 34 \% & 264 \% & -13 \%\end{array}$

$\begin{array}{lllll}\text { Dropping missing industry codes } & 788 \% & 58 \% & 333 \% & 2 \%\end{array}$

Sources: Top two panels: 1991 and 2006 MECS, Annual Survey of Manufactures. Bottom panel: 1963 and 2007

Census of Manufactures, 2009 Annual Survey of Manufactures 
Figure 1: Residential Electricity Use per Capita 1963-2009

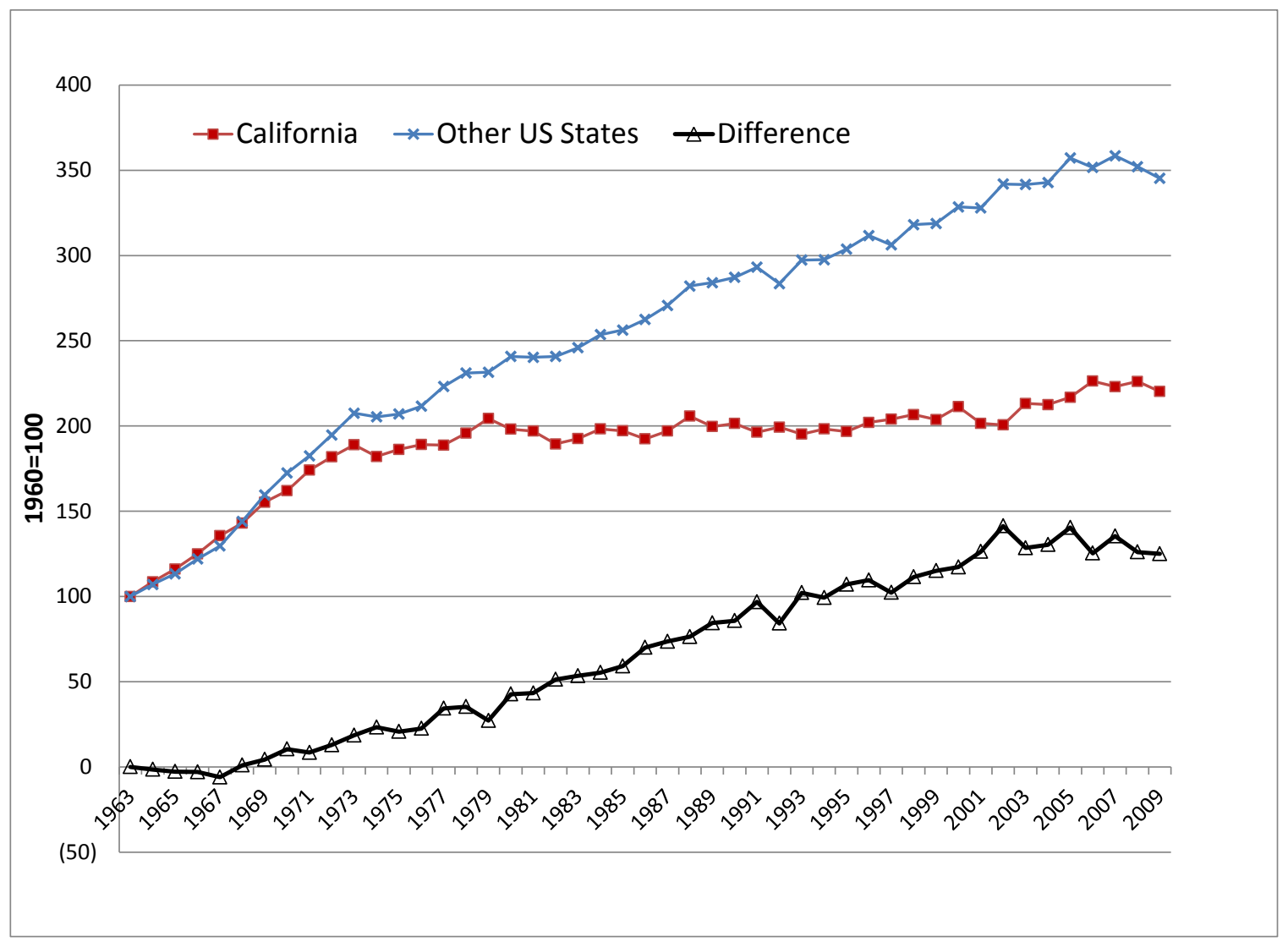

Figure 2: California Energy Savings 1963-2009

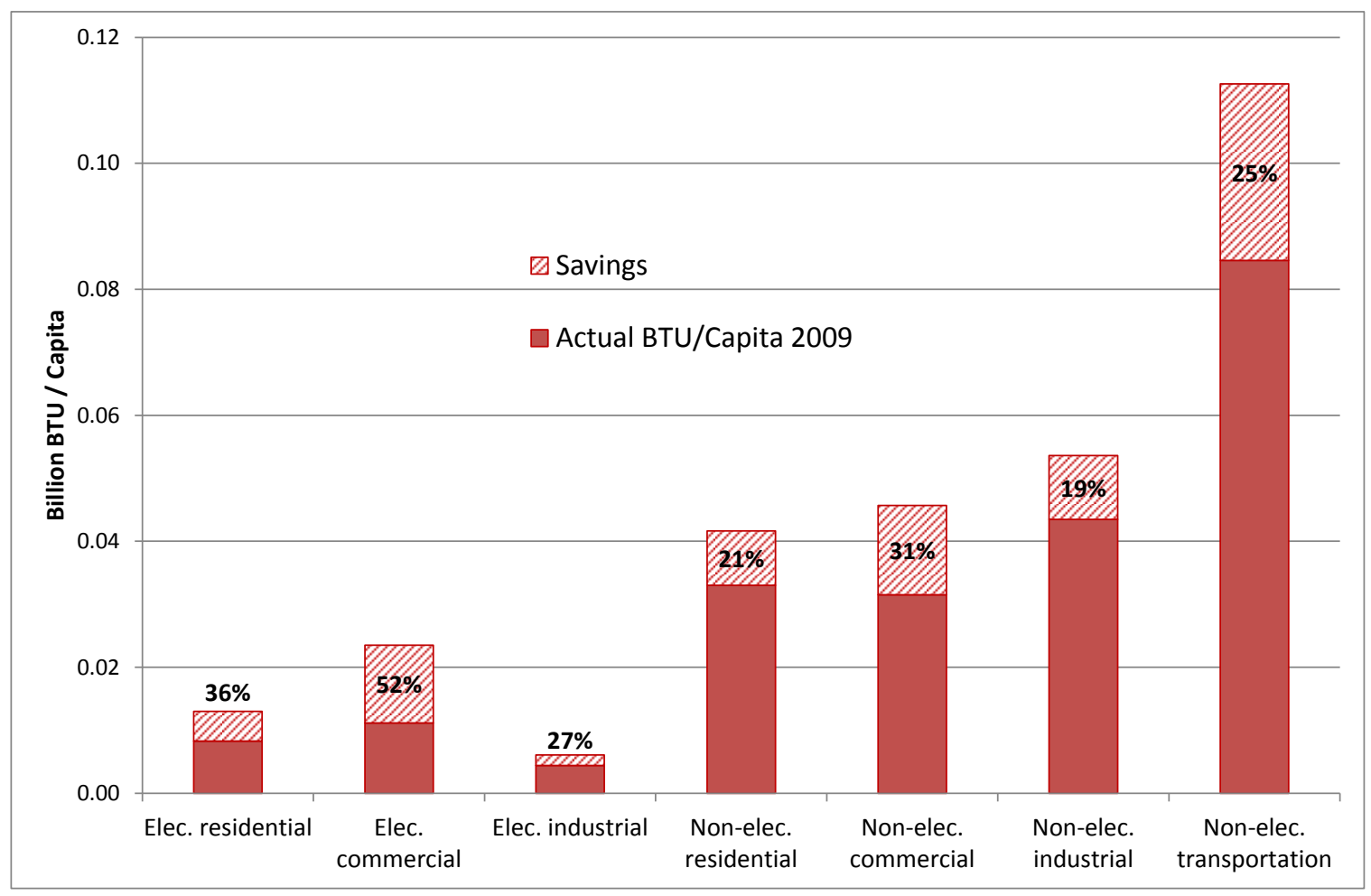


Figure 3: Population Shifts and Residential Electricity Use Per Capita

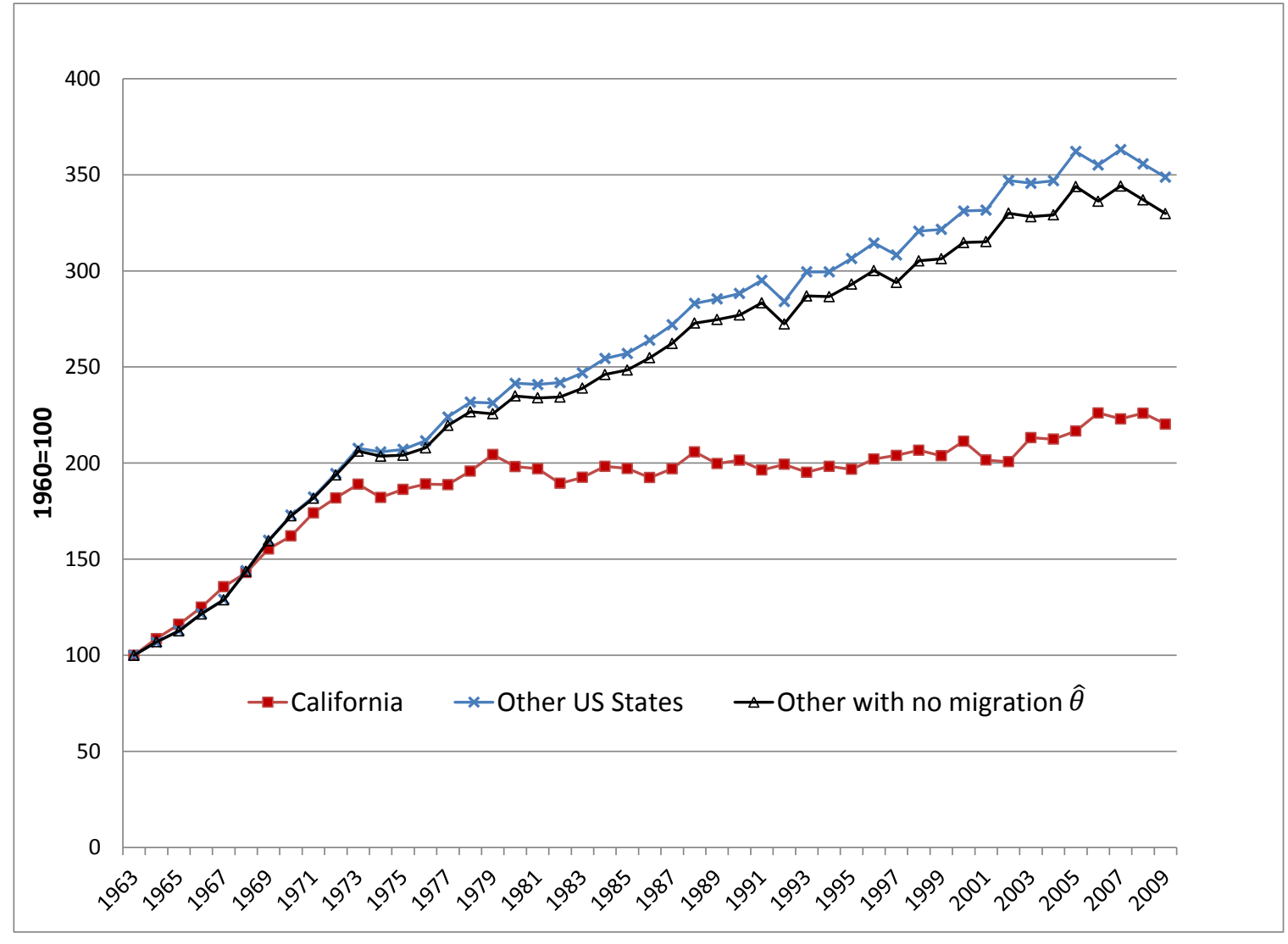

Figure 4: Population-weighted Heating and Cooling Degree Days 48 Contiguous States Aside from California

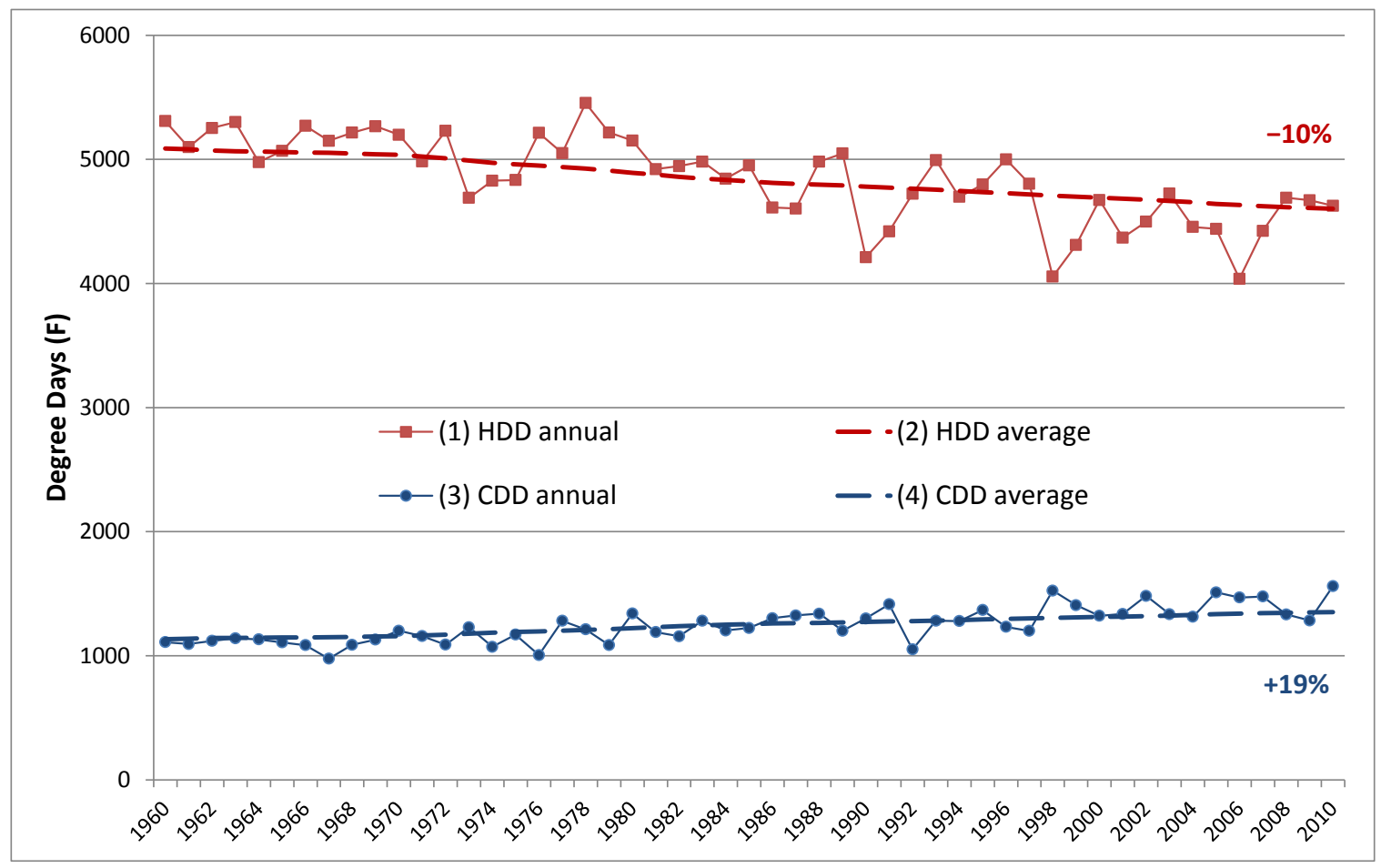


Figure 5: Residential Electricity Use by Household Size

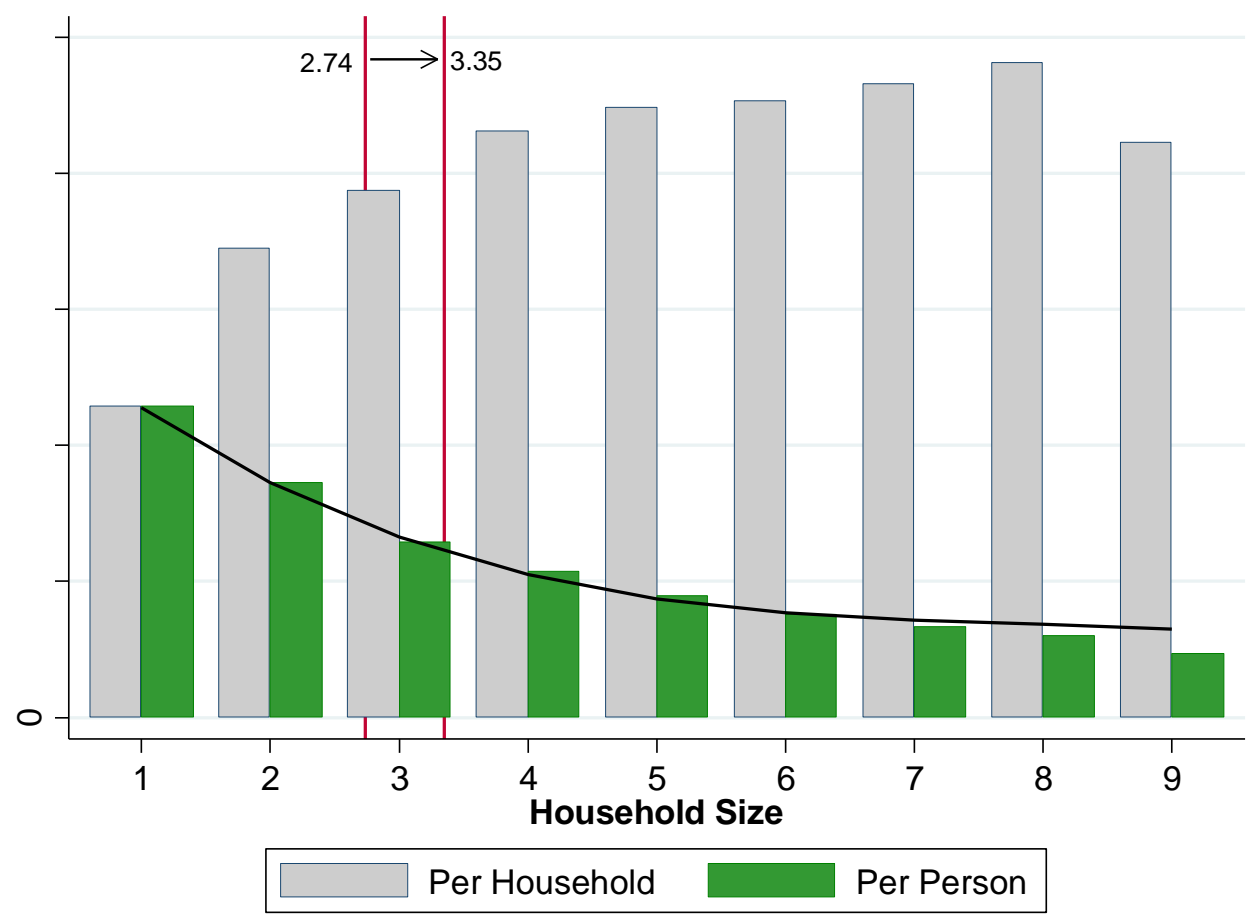

Figure 6: Changing U.S. Manufacturing Electricity Use

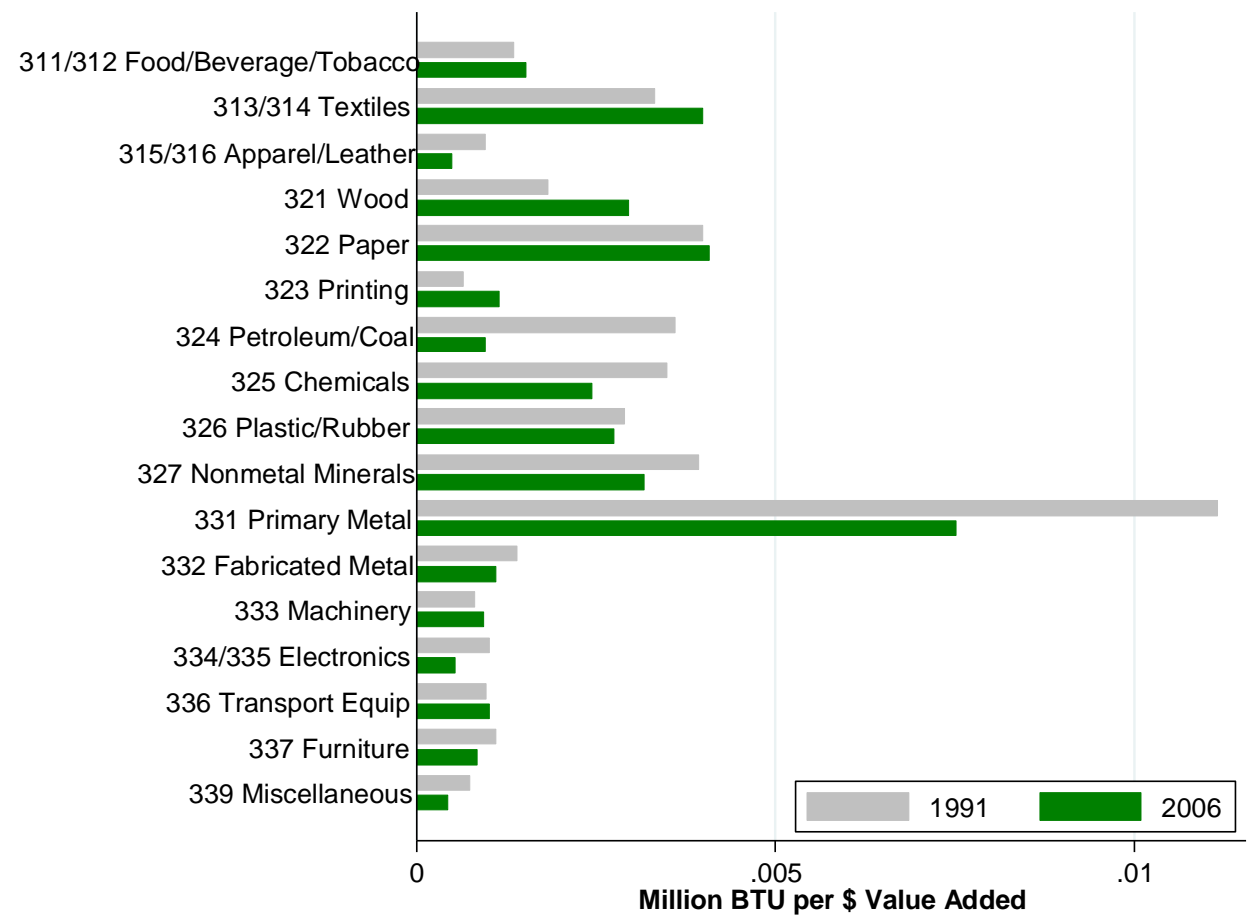


Figure 7: Changing Manufacturing Composition: 1963-2009
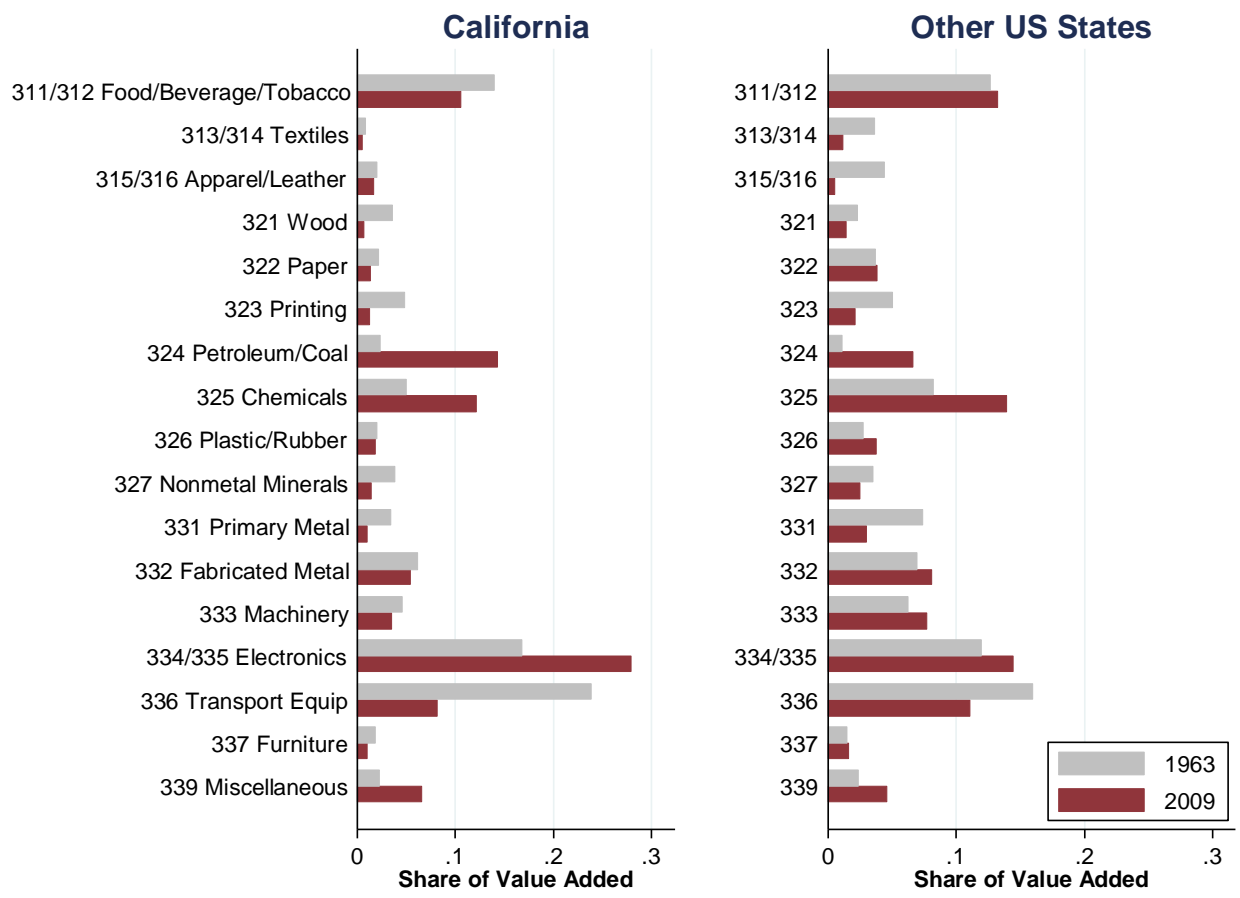

Figure 8: Predicted Manufacturing Electricity Use Per Capita: Based on 1991 MECS and Concurrent Industrial Composition

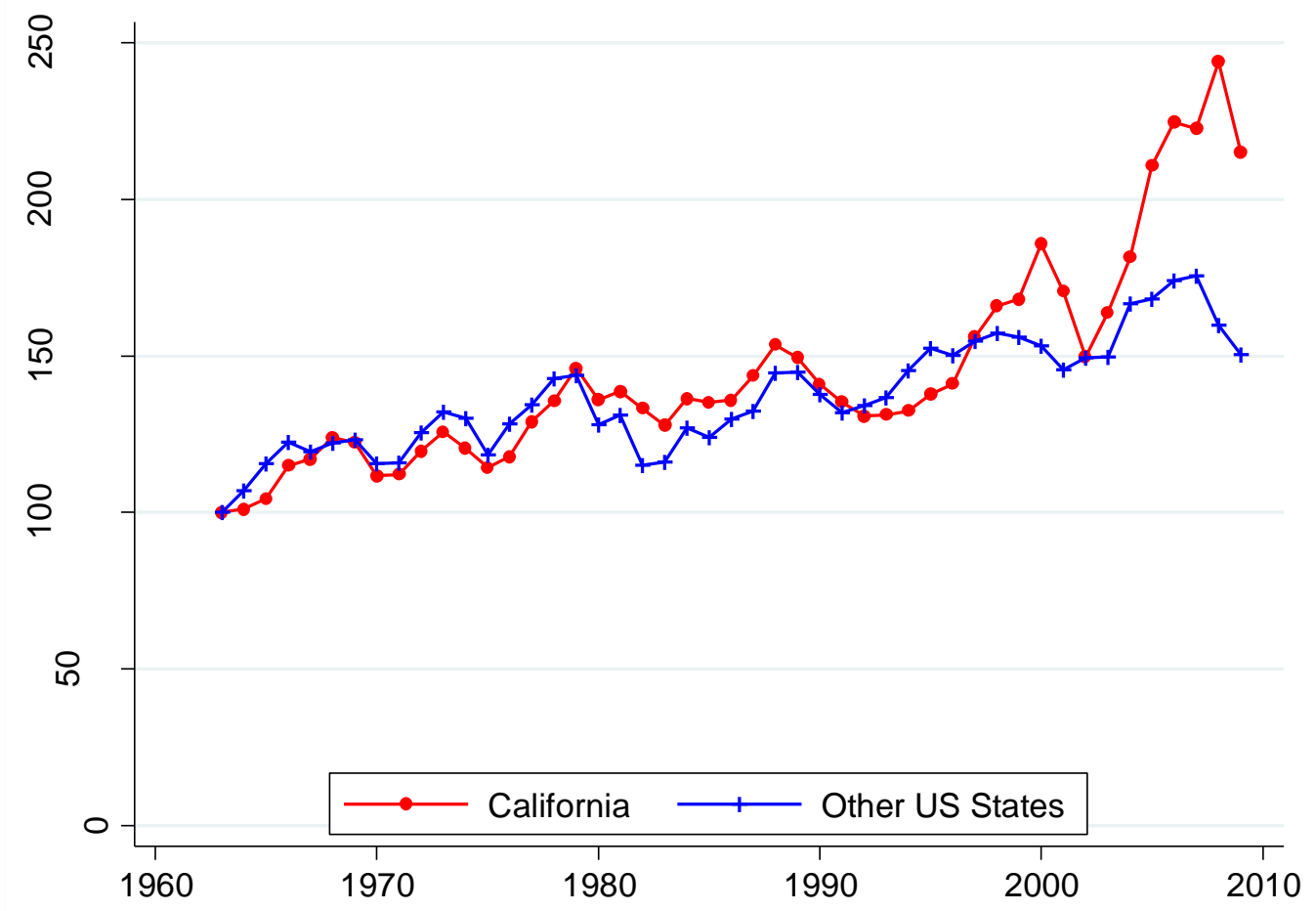


Figure 9: Motor Fuel Use per Capita

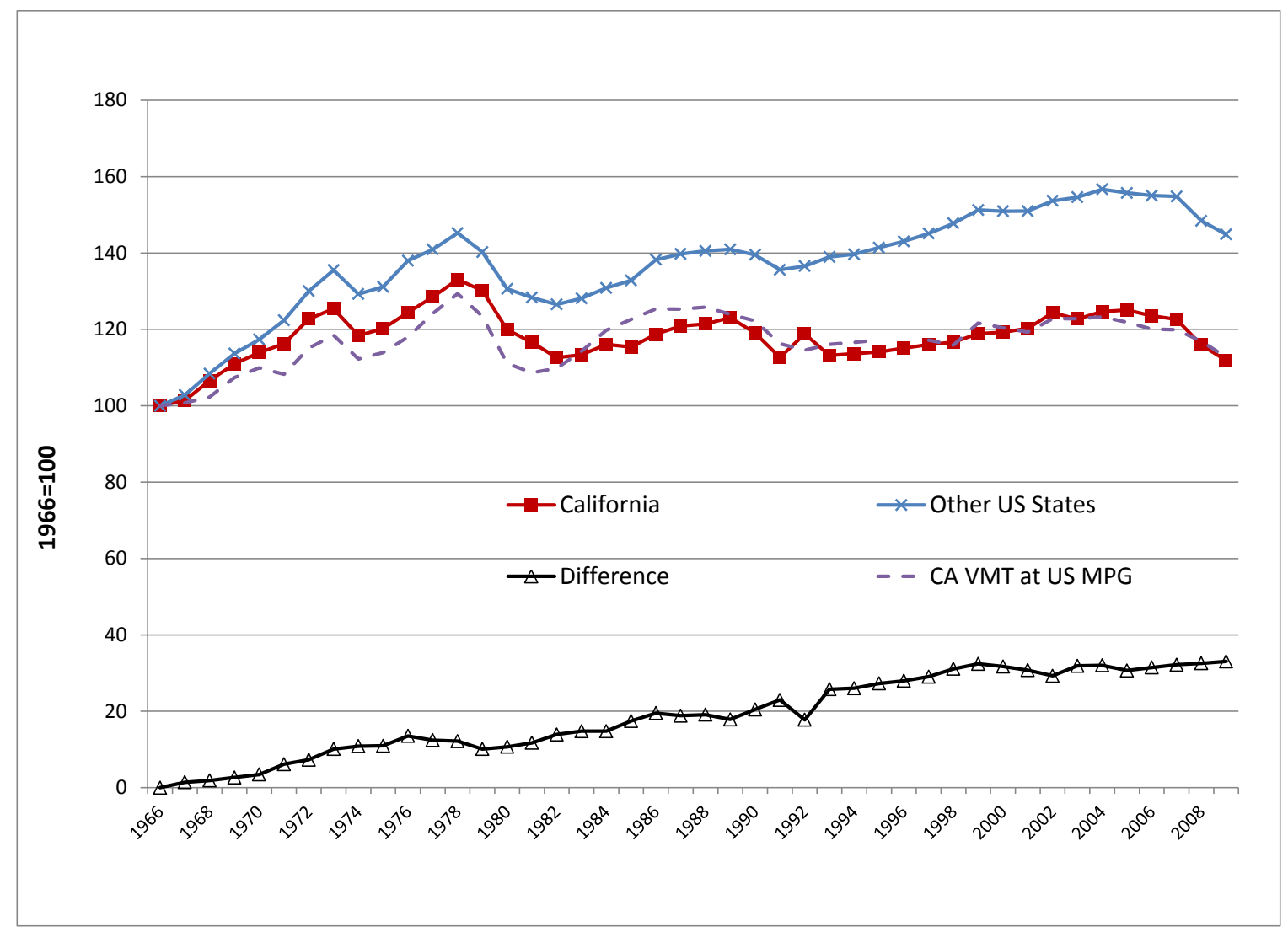

37 